\title{
State Capacity and Demand for Identity: Evidence from Political Instability in Mali*
}

\author{
Maxim Ananyev ${ }^{+}$and Michael Poyker ${ }^{\#}$
}

\section{Working Paper No. 97}

June 2019

\begin{abstract}
We demonstrate that civil conflict erodes self-identification with a nation-state even among nonrebellious ethnic groups in non-conflict areas. We perform a difference-in-difference estimation using Afrobarometer data. Using the onset of Tuareg-led insurgency in Mali caused by the demise of the Libyan leader Muammar al-Gaddafi as an exogenous shock to state capacity, we find that residents living closer to the border with the conflict zone experienced a larger decrease in national identification. The effect was greater on people who were more exposed to local media. We hypothesize about the mechanism and show that civil conflict erodes national identity through the peoples' perception of a state weakness.
\end{abstract}

JEL Codes: D74, H56, N47, O55, Z10.

Keywords: Conflict, National Identity, Media, Trust

${ }^{*}$ We are grateful to Graeme Blair, Ethan Bueno de Mesquita, Ruth Carlitz, Darin Christensen, Paul Dower, Stefano Fiorin, Amuitz Garmendia Madariaga, Jessica Gottlieb, Paola Giuliano, Erin Hartman, Jonas Hjort, Alexey Makarin, Tatiana Mayskaya, Lachlan McNamee, Vera Mironova, Richard Nielsen, Tom Pepinsky, Daniel Posner, Yuan Tian, Romain Wacziarg, conference participants at AALIMS, AEA, APSA, ASREC, MPSA, PACDEV, UC GEM-BPP Research Work- shop, and seminar participants at UCLA for excellent suggestions. All errors are ours. Correspondence at: Columbia Business School, Uris Hall 126, 3022 Broadway, New York, NY 10027.

+ University of Melbourne; e-mail address: maxim.ananyev@unimelb.edu.au

\# Columbia University; e-mail address: mp3780@columbia.edu 


\section{Introduction}

According to the 5th Afrobarometer survey (2011-2013), only slightly more than 50 percent of respondents in Sub-Saharan Africa view their national identity as more important than their ethnolinguistic group. The choice of national vs. ethnic identity is especially important in Sub-Saharan Africa because it directly affects economic development, public goods provision, corruption, and violence (Easterly and Levine (1997), Alesina, Baqir and Easterly (1999), Alesina et al. (2003), Cederman and Girardin (2007), and Baldwin and Huber (2010)). One of the plausible explanations of low levels of national identity is civil conflict. Countries of Sub-Saharan Africa experienced more than 80 intra-state wars between years 1960 and 2008 (Sarkees and Wayman (2010)). Empirically, the effect of civil conflict on identity formation remains unclear with some studies documenting the negative effect on generalized trust and increase in ethnic salience (Rohner, Thoenig and Zilibotti (2013)), and some studies documenting the positive effect of civil conflict on social cohesion (Gilligan, Pasquale and Samii (2014)). ${ }^{1}$ Importantly, existing literature only looks at the effect of civil wars on the attitudes of groups that are directly involved in conflict. This is a nontrivial limitation since, while the civil conflict does happen in Africa more often than in other parts of the world, most of the region's population lives far away from the conflict zones. ${ }^{2}$

In this paper, we exploit a plausibly exogenous timing of insurgency in Northern Mali to estimate the effect of civil conflict on the groups not directly affected by conflict. We hypothesize that members of those groups would view the state as weak and incapable, since the state is not able to resolve tensions and avoid or stop the insurgency. In addition, information about civil conflicts can break up the successful coordination of identities if people choose their identities not only based on their own views but also on their perception of other peoples' opinions. Using a representative geo-coded survey of Malian residents, we find — in a difference-in-difference framework that the proximity to the conflict area negatively affects national identity and increases the salience of ethnic identity. The effect is not driven by the pre-conflict differential trends, access to public goods, or security environments. The effect seems to be larger for those residents who consume more local media.

The Tuareg-led insurgency in Mali in 2012 provides a unique context to identify the causal effects of civil conflict on national identity. Generally it is difficult to do so because regions with lower national identity may be more prone to revolts against the nation state. Alternatively, some regions may be economically and politically different due to ethnic favoritism (e.g., Posner (2005)), which is correlated with national self-identification and propensity for violence. In our setting, the Tuaregs have been striving to win an autonomy for their homeland since Mali's independence, in 1960; however, the timing of the rebellion was plausibly exogenous to the Malian domestic political developments because it was a direct result of NATO's involvement in the Libyan civil

\footnotetext{
${ }^{1}$ Other studies documenting the same phenomenon are summarized in Bauer et al. (2016).

${ }^{2}$ The number of people living within a 50 -kilometer radius of conflict events is estimated at 840 million, or $12 \%$ of the world's population (Bahgat et al. (2018)).
} 
war. ${ }^{3}$ This exogenous shock of insurgency allows us to address reverse causality coming from the ethnic conflict as being a symptom of weak national identity. Second, we address the latter concern (i.e., omitted variable bias), as we concentrate our analysis on the non-conflict areas and do not consider Tuaregs or Tuareg homelands.

Our institutional setting is the Tuareg-led insurgency in Mali caused by the demise of the Libyan leader Muammar al-Gaddafi. The Tuaregs first were hired by Muammar al-Gaddafi when the Libyan civil war started; they then returned to their homelands with their weapons after the Libyan regime had been defeated by NATO-led coalition. Three of the country's nine regions Tomboctou, Kidal, and Gao (collectively known as Azawad), all located in the northern Mali are considered Tuareg homelands and have been the subject of a struggle for independence. Importantly, in our analysis we consider only non-Azawad regions (the border region of Mopti and other regions to the south of Azawad).

Thus, our identification is based on a variable-treatment-intensity difference-in-difference estimation, where we compare respondents living closer to the border with Azawad to those living further away before and after the conflict; i.e., our treatment - proximity to Azawad's border is continuous. While respondents did not experience the damaging effects of the conflict in person, these residents were exposed to information about state weakness due to the rebellion. This exposure came from two factors. First, the violence in Azawad triggered a refugee crisis that saw up to 400,000 Malians leaving their homes. Those refugees who wanted to move to more peaceful southern regions had to go southward from Azawad through Malian territory. ${ }^{4}$ Second, Malian army forces conducting antiterrorist fighting moved through Mali to get to Azawad. ${ }^{5}$ Army operations near the Azawad's border led to civilian casualties and triggered intercommunal violence. Residents located closer to the border were therefore more informed regarding the state's weakness. ${ }^{6}$

We show a negative causal effect of state weakness on national identity using individual-level survey data from Mali. We use the third, the fourth, and the fifth Afrobarometer surveys, which were completed before (2005 and 2008) and right after the insurgency (2012), to construct the measure of national identity and measure the distance between border with Azawad and the respondent. We find substantial adverse effects of the civil conflict on national identity. We find that national self-identification of the respondents located 100 kilometers closer to the border with Azawad experienced a 19.7 percentage-points larger decrease than those located further away. Given that before the latest instance of the Tuareg rebellion the share of people who had chosen the national identity was 69 percent, this is a substantial effect. We also provide suggestive evidence that respondents who were located closer to the conflict zone and had higher exposure to media or were members of local community groups (conditional on other socio-demographic factors) experienced an even larger decline. One of the potential explanations for this heterogeneous effect is

\footnotetext{
${ }^{3}$ The Tuareg insurgency is often called an "unintended consequence" of NATO's operation in Libya (Shaw (2013)).

${ }^{4}$ UNICEF and The UN Refugee Agency, 2018.

${ }^{5}$ Hrw.org, 2017.

${ }^{6}$ Villages in our analysis have not suffer large-scale violence in the period of study and all specifications are robust to inclusion controls on the presence of armed forces and terrorist activity.
} 
that receiving more information about the rebellion led people to reconsider their identities faster.

We perform a series of tests to address concerns regarding identifying assumptions and rule out alternative explanations for our findings. Our results are robust to the specification with regional or administrative districts fixed effects. To address the concern on the existence of possible differential pretreatment trends we control for village/town-specific linear trends. We address possible mean-reversal by controlling for lagged mean national identity. We also show that lower national identity salience was not explained by (i) worsening of local economic conditions, public goods provision, or increased violence; (ii) atrocities perpetrated by the Malian government; (iii) ethnic or ideological proximity of survey respondents towards the Tuaregs; (iv) changes in social cohesion and trust. We also check whether our results were driven by a particular subsample. We find that our results did not differ for the set of rural or urban, or Muslim and non-Muslim respondents, or majority and minority ethnic groups.

To investigate the channels of influence of conflict on national identity, we perform the same difference-in-differences estimations using several potential channels: trust in a national leader, trust in parliament, and trust in local leaders. We find that only changes in trust in national leader can be predicted by the distance from conflict zone, while other variables are not affected. We also find that the trust in national leader is a strong predictor of national identity. In an instrumentalvariable (IV) analysis following the framework of Dippel et al. (2017), we find, specifically, that the variation in trust in national leader, which is explained by the distance from the conflict zone, can also by itself strongly predict changes in national identity. This result is consistent with people reconsidering their identities based on the perceived strength of national government, which itself is influenced by their proximity to conflict.

We make several contributions to the literature. Our paper is the first to show that civil conflicts erode national identity in non-conflict areas. There are almost no papers studying the effects of conflicts on the non-conflict area, with a notable exception of Makarin and Korovkin (2018) who studied the effects of armed conflict in Donbas, Ukraine on trade. Previous studies on the effects of conflict on identity formation focus almost fully on the direct effects of violence in international warfare (summarized in Bauer et al. (2016)) or in the war zones (Rohner, Thoenig and Zilibotti (2013)). For example, Dell and Querubin (2018) show that territories affected by U.S. bombardments during the Vietnam War experienced a rise in communist insurgency. We argue that when it comes to internal warfare the effect can go the other way: civil conflicts can erode national identity.

Our paper also contributes to the literature on endogeneity of ethnic identities. Multiple studies have shown that identity depends on economic conditions (Laitin (1998), Shayo (2009)) and on political coalitions (Posner (2004b), Eifert, Miguel and Posner (2010)). We show that it is endogenous to state weakness. This argument is important because many economic theories of civil wars theorize about civil conflict as a contention between fixed ethnic groups (Besley and Persson (2009, 2010)). While those theories have important implications, we show that they might diverge from the empirics in treating ethnic identities as immutable. In this respect our findings are consistent with the constructivist view on identity formation (Kalyvas (2008)). 
Our study is also relevant for the "conflict trap" literature. Multiple studies have documented that having a civil conflict is associated with the higher probability of a subsequent conflict (Collier et al. (2003), Kibris (2015), and Braithwaite, Dasandi and Hudson (2016)). Our findings suggest a plausible mechanism for the conflict trap - making ethnic identities more politically salient. Since fractionalization along more politically salient ethnic identities is associated with a variety of negative economic outcomes and conflict (Posner (2004a), Bhavnani and Miodownik (2009)), our study provides a missing a link that connects conflict with more conflict through endogenous identity formation of the members of groups not directly involved in violence.

More generally, our study contributes to the literature exploring one of the understudied aspects of economic development in fragile nations - a social construction of nation, an "imagined community" that the citizens of a country see themselves belonging to. ${ }^{7}$ This paper explores the formation of identities using data from developing nations contributing to the economic and political science literature (Laitin (1998), Miguel (2004), Posner (2004b), Eifert, Miguel and Posner (2010), and Robinson (2014)). Our paper also contributes to a growing economic literature on the determinants of national identity in developed and developing countries (Alesina and Reich (2015), Alesina, Reich and Riboni (2017), and Depetris-Chauvin, Durante and Campante (2018)).

The paper is organized as follows. Section 2.1 describes the data. Section 2 presents background information about the Tuaregs. Section 3 explains our identification strategy, contains the main empirical results, and explores the sensitivity of our results to alternative explanations. Section 5 concludes.

\section{Tuareg Rebellion in Mali: Background and Data}

\subsection{Data}

We use several datasets. The individual data before and after the start of the 2011-2012 insurgency come from the second (2002), third (2005), forth (2008), and fifth (2012) waves of Afrobarometer survey. As we can use only data for those countries that are present in both waves before and after the start of the Tuareg insurgency — we restrict ourselves to the study of Mali. We construct a repeated cross-section of individuals in four Afrobarometer waves spanning from 2002 to 2012. We have also obtained GPS coordinates of all the respondents.

The main variable of interest is national identity $\left(N I_{i t}\right)$. Following Eifert, Miguel and Posner (2010) and Depetris-Chauvin, Durante and Campante (2018), we construct it as an indicator variable by using the question about whether a respondent considers "national identity" their primary identity. The question is asked as follows: "Let us suppose that you had to choose between being a Malian and being a [Respondent's Ethnic Group]. Which of the following best expresses your feelings?" These are the possible answers: (i) I feel only (R's ethnic group); (ii) I feel more (R's ethnic group) than Malian; (iii) I feel equally Malian and ( $R$ 's ethnic group); (iv) I feel more Malian than (R's ethnic group);

\footnotetext{
${ }^{7}$ Sociologists, political theorists, and historians have been contributing to this question (Anderson (2006), Gellner and Breuilly (2008), Hobsbawm (2012), Mann (2012), and Sambanis and Shayo (2013)).
} 
(v) I feel only Malian. If a respondent answers that he/she considers only "national identity" their primary identity, we assign the value of 1 to the $N I_{i t}$ and 0 otherwise.

Mali's second, third, and fourth Afrobarometer samples contain information on all of Mali's regions. The fifth sample contains information only about six southwestern regions of Mali as three northeastern regions were considered dangerous because of the insurgency and enumerators avoided them. At the same time, other regions were interviewed in the same manner, and mostly the same villages and cities.

We describe the data construction for our control variables in Appendix B.

\subsection{Background and Motivational Facts}

Scholars of the region (e.g., Shaw (2013)) conclude that "conflict in Mali did occur as the result of escalation and diffusion/contagion mechanisms from the Libyan Civil War." At the time of unrest, Colonel al-Gaddafi used his vast financial resources to train, arm, and fund large numbers of Tuaregs - a seminomadic ethnic minority group. Conflict in Mali did occur as the result of escalation and diffusion/contagion mechanisms from the Libyan Civil War. When Gaddafi died, the Tuaregs took their guns back to their homelands - regions of Algeria, Mali, Niger, and Burkina Faso - and attempted to take control of those territories. In Mali, they led a full-fledged rebellion and, for a time, seized the country's northern half. ${ }^{8}$ As a result, in March 2012, Mali's army officers, dissatisfied with the government's weak response to the Tuareg insurgency, organized a coup and ousted the democratically elected Malian president, Amadou Toumani Touré.

Figure 1: Severity of the terrorist attacks in Mali

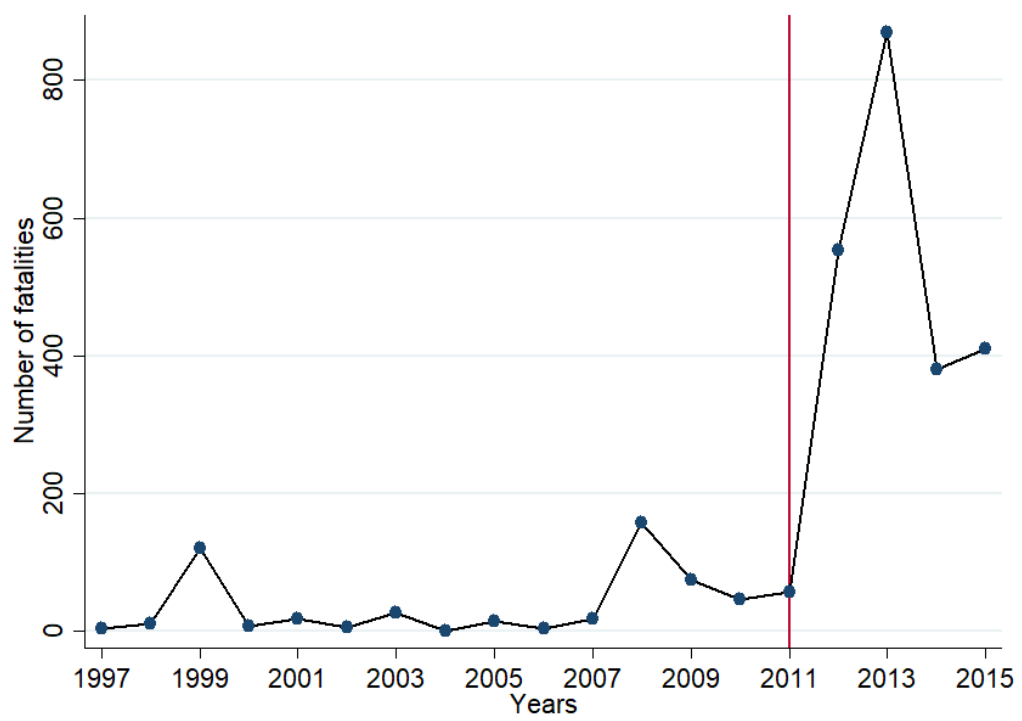

Notes: The Figure shows numbers of people killed and wounded in Mali from 1997 to 2015. Source: Computed with Armed Conflict Location \& Event Data Project (ACLED Version 6) data.

\footnotetext{
${ }^{8}$ Foreign Policy, 2012.
} 
The location of the insurgency was not random as it happened in the ethnic homelands of a particular group: the Tuaregs (see Figure 6). However, the timing was influenced by the abrupt regime change in Libya, and was exogenous to Malian local economic conditions. As a visual example of insurgency, Figure 1 depicts the total number of people killed and wounded due to terrorist attacks in Mali. We can clearly see the spike in the number of deaths after 2011.

This insurgency gives us a unique setting because it is driven not by ethnic cleavages and the insurgency was perceived as a sign of state weakness (which is almost tautological, because the existence of an active insurgency means that the state is not fully capable of maintaining a monopoly on violence). At the same time, this insurgency happened in the country where we have reliable data on the salience of ethnic and national identities in the years before the insurgencies and thus can explore the potential effects of the insurgencies.

Figure 2 visualizes our main finding by demonstrating the reduced form relationship between the distance to the conflict zone (i.e., Azawad) and changes in national identity among Malian respondents between 2008 and 2012. Respondents living in villages and towns located closer to the border with Azawad experience a higher decline in national identity after the insurgency.

Figure 2: Distance to Azawad and changes in national identity between 2008 and 2012

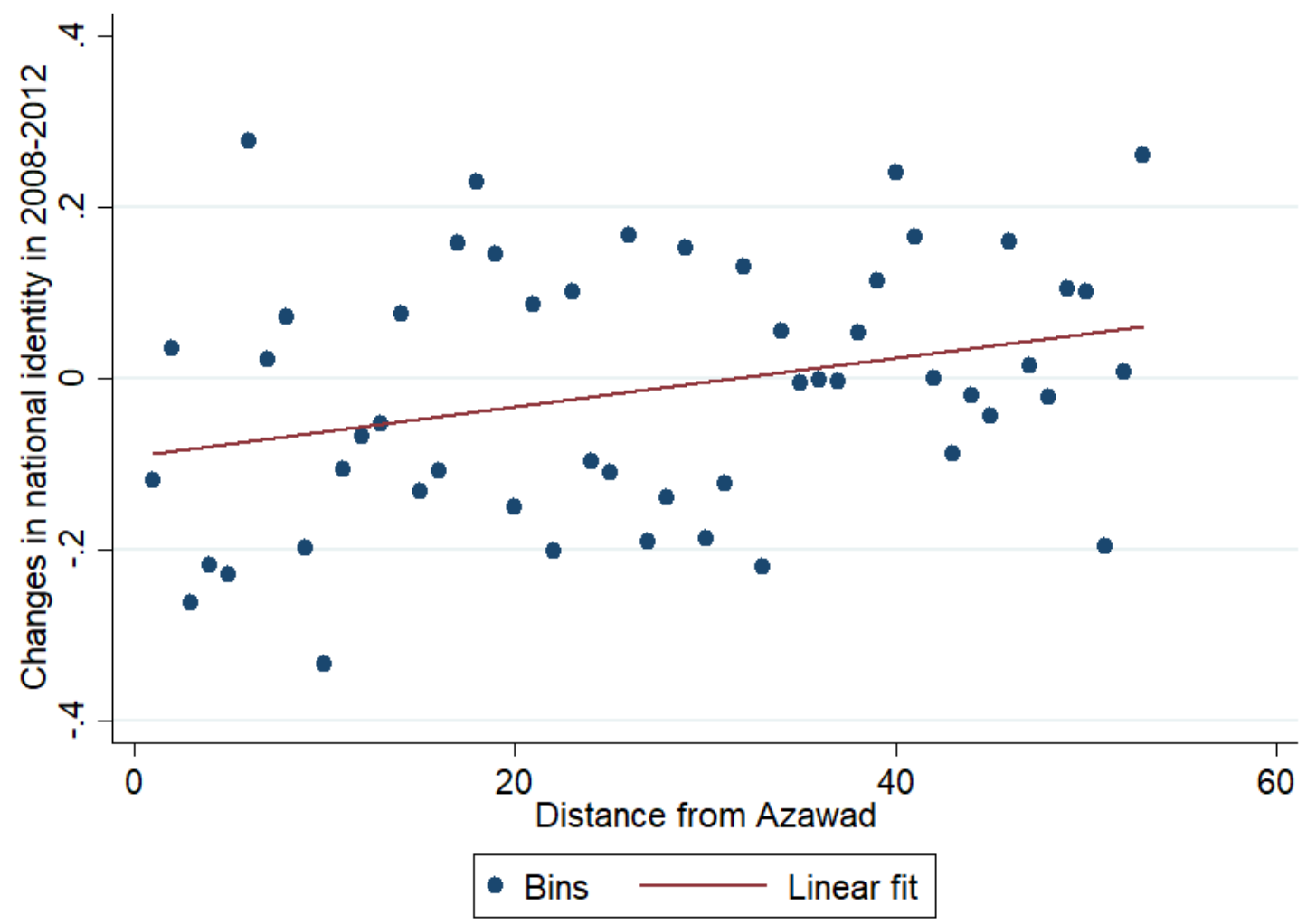

Notes: Observation is a bin; i.e., all villages/towns are grouped in 55 bins for the sake of better representation. The blue dot represents the residualized differences between national identity before and after the Tuareg Rebellion.

For the sake of visual representation of the pre-trends we split all respondents in two groups: 
those dwelling in the region that borders Azawad to the south (within 250 kilometers) - Mopti, and the rest of the Mali. Because Mopti shares the common border with Azawad, we hypothesize that its residents must be more exposed to state weakness due to the rebellion. In Figure 3, the blue line represents the treatment group (Mopti), and the red line represents the control group (the rest). We see that before the insurgency, the average levels of national identity had been increasing in all the regions. Right after the start of the insurgencies, the level of national identity in the control group continued to increase, but in the treatment group it went down rapidly. In the next section we directly control for village/town-level trends.

Figure 3: Pretreatment trends in national identity

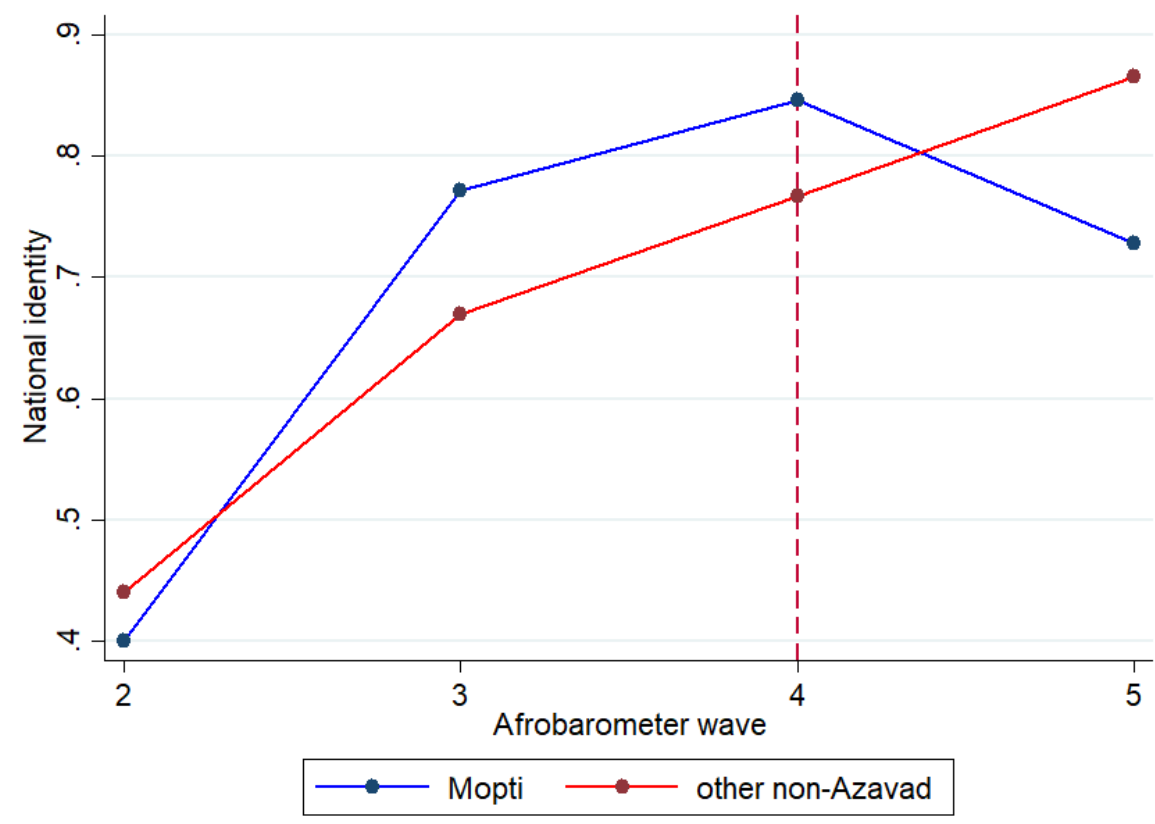

Notes: The blue line represents the average values of the national identity in Mopti. The red line represents the average values of national identity in other non-Azawad regions (Bamako, Kayes, Koulikoro, Ségou, and Sikasso).

\section{Empirical Strategy and Results}

\subsection{Empirical Strategy and Identification}

Our main hypothesis is that an insurgency has a negative causal effect on national self-identification. We start with a variable-treatment-intensity difference-in-differences estimation where treatment is a continuous variable, assuming, that villages located closer to the Azawad's border are more treated than those located further away (in a time period when the conflict has started). The specification is as follows:

$N I_{i(c) t}=\alpha+\beta$ Distance to Azawad $_{c}+\delta\left(P O S T_{t} \times\right.$ Distance to Azawad $\left.c\right)+X_{i t}^{\prime} \Gamma+\mu_{r}+\lambda_{t}+\varepsilon_{i t}$, 
where as a dependent variable we use a dummy $N I_{i(c) t}=0$ if respondent $i$ nested within village/town $c$ has identified herself with her ethnic group at time $t \in\{2005,2008,2012\}$ and equal to unity if she identifies herself with the nation. Variable $P O S T_{t}$ is a dummy equal to unity if $t=2012$; Distance to Azawad $_{c}$ is an inverse minimum distance from village/town $c$ to the border with Azawad and defines exposure for state weakness; $X_{i t}$ is a matrix of individual controls such as age, education, dummy for rural area, household wealth index, religion, and ethnicity; and $\mu_{r}$ and $\lambda_{t}$ are region and year fixed effects. Because geographical coordinates are available at the village/town level, so is our treatment. Thus, we cluster errors on the village/town level as well. In brackets we also report standard errors double-clustered by the village/town-Afrobarometer's wave. ${ }^{9}$

This estimation allows us to rule out the existence of unobserved region-specific and yearspecific factors that could bias our estimates. We also control for geographic coordinates and the distance to capital-Bamako to address possible spatial correlation between the rule of law and national identity. Using lagged region-level national identity we control for possible mean-reversal in all specifications.

Thus, we use two types of variation: geographical (how closely the respondent is located to insurgency) and temporal (whether the particular wave of the survey happened after the increase in violence). The coefficient of the interaction of the distance to Azawad and the post-insurgency year dummy $(\delta)$ is the effect of the information about state weakness in the non-conflict zone when the rebellion had happened. We expect it to be negative.

As Tuaregs may be more likely to choose ethnic identity over national identity because of the Tuareg-led rebellion, we could overestimate the effect of insurgency. Thus, we drop all individuals whose ethnic group is Tuareg; these constitute 2.8 percent of the observations.

\subsection{Results}

Results of the OLS estimations are presented in Table 1. Column I, shows the results of the specification with time and regional fixed effects without any individual controls. The coefficient of interest is negative and highly significant: being 100 kilometers closer to insurgency decreased residents' national identification by 46.5 percentage-points. Column II, controls for possible meanreversal in the dependent variable by adding lagged region-level national identity. The resulting coefficient remains significant but substantially decreases in magnitude.

In Columns III-IV, to discern whether urban population or Muslim/Christian affiliation had different reactions on insurgency, we add an indicator variable for urban respondents, and dummies for religions. We also control for age, gender, personal living conditions, education, unemployment, access to news, first principal component of household assets, and ethnicity fixed effects. Results hold in Columns V and VI, where we control for latitude, longitude, and the distance to the capital. Finally, in Column VII we directly control for regional-level pre-trends in national

\footnotetext{
${ }^{9}$ In Table 17, we also report a robustness check with spatial HAC standard errors in case there are omitted variables correlated with distance to Azawad and post-treatment year but not correlated with the national identity.
} 
identity (i.e., six trends for non-Azawad regions); our results hold. Overall, being 100 kilometers closer to insurgency decreased residents' national identification by 36.9 percentage-points.

One of the explanations behind the relative decrease in national self-identification of Malians located closer to the conflict zone could be through the substitution of national identity with ethnic identity as their primary identity. Thus, results for ethnic identity should be mirror results for the effect of civil conflict on national identity above. We explore this channel in Table 2 where we repeat Table 1 but with ethnic identity as the dependent variable. ${ }^{10}$ The results suggest that being 100 kilometers closer to insurgency increased residents' ethnic identification by 9.8 percentagepoints. These results suggest that at least a third (and at most three quarters) of the decline in national identity was substituted with the rise in ethnic identity as a result of civil insurgency.

Table 1: Civil conflict and national identity: Individual-level data

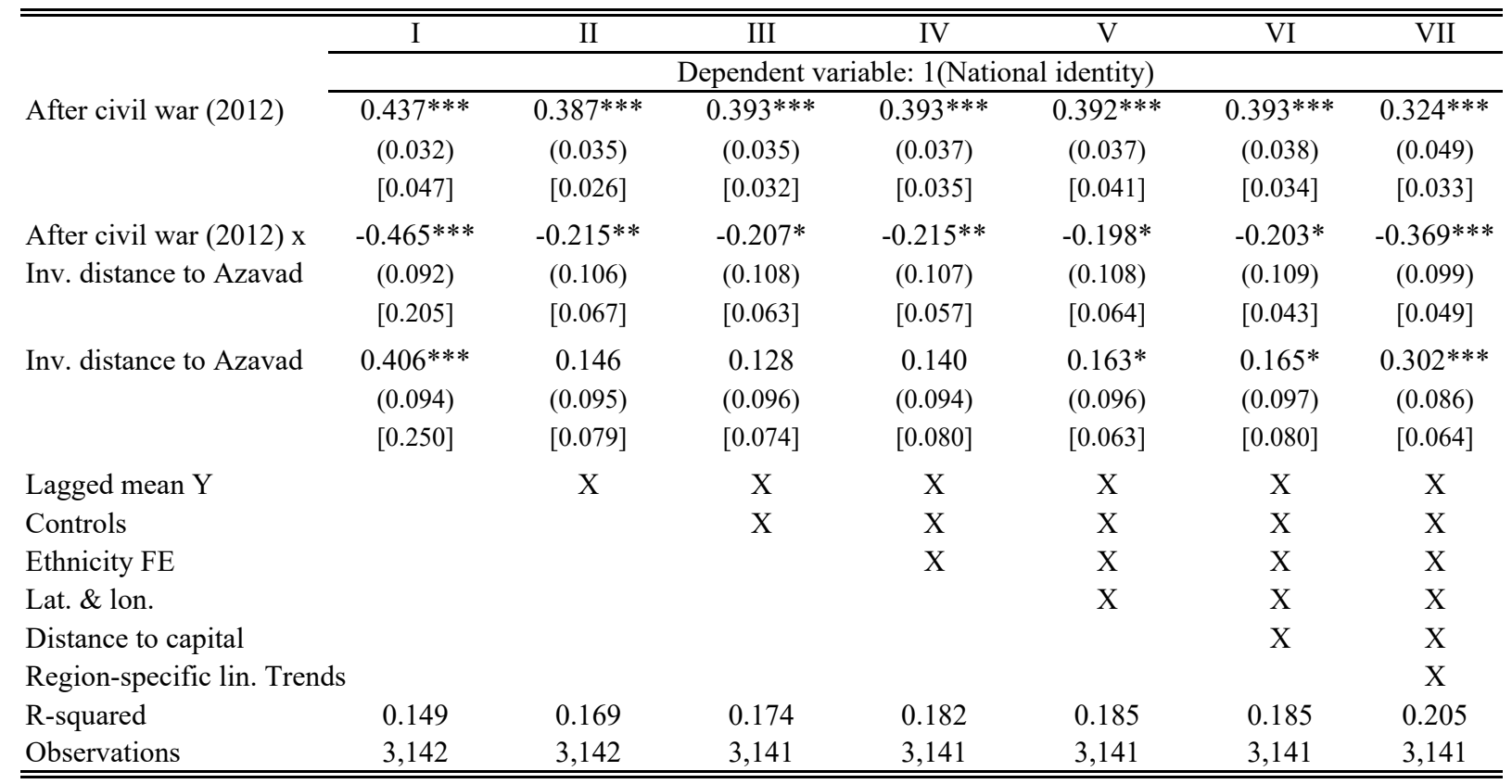

Notes: All columns include constant and regional fixed effects. The following variables are included as controls: urban dummy, religion dummies (Christian, Muslim, and traditional beliefs), age, age squared, gender dummy, dummy for positive change in living conditions, dummy for unemployment, dummies for secondary and tertiary education, dummy for daily access to news, and wealth index. Robust clustered-by-geographical location standard errors are in parentheses. 247 clusters. ${ }^{* * *} \mathrm{p}<0.01,{ }^{* *} \mathrm{p}<0.05,{ }^{*} \mathrm{p}<0.1$

Our results are robust to usage of different empirical specifications and controls. Table 17 reports results for the similar specifications but with alternative, less strict, measures of national identity: (i) equal to one if a respondent not only feels only Malian, but also if feels Malian more than her ethnic group (Column II), (ii) equal to one if a respondent feels Malian at least as her ethnic group (Column III). Results hold if we use spatial-HAC standard errors in Column IV or if we use different weights. ${ }^{11}$ Results also hold if, in Column VI, instead of six region-specific trends

\footnotetext{
${ }^{10}$ Controlling for region-specific linear trends make the interaction marginally insignificant with village-level clustering ( $\mathrm{p}$-value=0.11); however, it remains significant with village-wave double-clustered standard errors, or spatial HAC standard errors.

${ }^{11}$ We use reg2hdfespatial command in Stata. The after-civil-war-(2012) dummy is absorbed.
} 
we use 247 location-specific linear trends, or if we also control for district fixed effects. The latter specification is very demanding since we compare the distance to conflict between villages/towns within the same districts (nested within regions). ${ }^{12}$ Finally, in Columns VIII and IX, we control for the number and severity of terrorist attacks near the respondents' region. Both coefficients are negative and significant, suggesting that national identity decreased more in regions with terrorist attacks. However, the interaction of distance to Azawad and $P O S T_{t}$ remains highly significant.

Table 2: Civil conflict and ethnic identity: Individual-level data

\begin{tabular}{|c|c|c|c|c|c|c|c|}
\hline \multirow{5}{*}{ After civil war (2012) } & $\mathrm{I}$ & II & III & IV & $\mathrm{V}$ & VI & VII \\
\hline & \multicolumn{7}{|c|}{ Dependent variable: 1 (Ethnic identity) } \\
\hline & $-0.100 * * *$ & $-0.292 * * *$ & $-0.259 * * *$ & $-0.238 * * *$ & $-0.234 * * *$ & $-0.229 * * *$ & $-0.363 * * *$ \\
\hline & $(0.020)$ & $(0.058)$ & $(0.060)$ & $(0.061)$ & $(0.062)$ & $(0.061)$ & $(0.085)$ \\
\hline & {$[0.016]$} & {$[0.067]$} & [0.089] & {$[0.086]$} & {$[0.085]$} & {$[0.086]$} & {$[0.027]$} \\
\hline After civil war (2012) x & $0.247 * * *$ & $0.232 * * *$ & $0.237 * * *$ & $0.227 * * *$ & $0.185 * * *$ & $0.159 * *$ & $0.098^{*}$ \\
\hline \multirow[t]{2}{*}{ Inv. distance to Azavad } & $(0.070)$ & $(0.071)$ & $(0.071)$ & $(0.072)$ & $(0.069)$ & $(0.066)$ & $(0.062)$ \\
\hline & [0.089] & {$[0.072]$} & {$[0.054]$} & {$[0.060]$} & {$[0.045]$} & {$[0.065]$} & {$[0.023]$} \\
\hline \multirow[t]{3}{*}{ Inv. distance to Azavad } & $-0.218 * * *$ & $-0.196 * * *$ & $-0.203 * * *$ & $-0.197 * * *$ & $-0.160 * * *$ & $-0.152 * * *$ & $-0.124 * *$ \\
\hline & $(0.059)$ & $(0.055)$ & $(0.054)$ & $(0.055)$ & $(0.052)$ & $(0.052)$ & $(0.051)$ \\
\hline & {$[0.126]$} & {$[0.117]$} & {$[0.095]$} & {$[0.098]$} & {$[0.087]$} & {$[0.098]$} & {$[0.053]$} \\
\hline Lagged mean $Y$ & & $X$ & $X$ & $\mathrm{X}$ & $X$ & $X$ & $X$ \\
\hline Controls & & & $\mathrm{X}$ & $\mathrm{X}$ & $\mathrm{X}$ & $\mathrm{X}$ & $\mathrm{X}$ \\
\hline Ethnicity FE & & & & $X$ & $\mathrm{X}$ & $\mathrm{X}$ & $\mathrm{X}$ \\
\hline Lat. \& lon. & & & & & $\mathrm{X}$ & $\mathrm{X}$ & $\mathrm{X}$ \\
\hline Distance to capital & & & & & & $\mathrm{X}$ & $\mathrm{X}$ \\
\hline Region-specific lin. Trends & & & & & & & $\mathrm{X}$ \\
\hline R-squared & 0.024 & 0.029 & 0.038 & 0.051 & 0.053 & 0.056 & 0.068 \\
\hline Observations & 3,142 & 3,142 & 3,141 & 3,141 & 3,141 & 3,141 & 3,135 \\
\hline
\end{tabular}

Notes: All columns include constant and regional fixed effects. The following variables are included as controls: urban dummy, religion dummies (Christian, Muslim, and traditional beliefs), age, age squared, gender dummy, dummy for positive change in living conditions, dummy for unemployment, dummies for secondary and tertiary education, dummy for daily access to news, and wealth index. Robust clustered-by-geographical location standard errors are in parentheses. 247 clusters. ${ }^{* * *} \mathrm{p}<0.01,{ }^{* *} \mathrm{p}<0.05,{ }^{*} \mathrm{p}<0.1$

In Online Appendix C.2 we provide additional robustness checks. To address possible unobserved spatial autocorrelation we use an arbitrary "treated" region - Mopti located to the south of Azawad - that was exposed to the insurgency but did not suffer insurgency itself. This specification yields similar results. It is worth noticing, that essentially instead of having a continuous treatment, here we assign 0 for all locations that lie father than 250 kilometers away from the conflict zone and 1 for all respondents living within 250 kilometers from the border.

\subsection{Alternative Explanations}

In this section, we demonstrate that our results are not driven by (i) Azawad's major ethnic groups in southern Mali sympathizing with the rebel groups; (ii) residents observing atrocities of the state in rebellious areas and disliking it; (iii) the fact that individuals in a conflict area receive

\footnotetext{
${ }^{12} 75 \%$ of the districts have only one village/town, thus we identify the effect of civil conflict only from a quarter of all observations.
} 
less benefit from the national identity because the government fails to provide them with economic security, public goods, or protect them from violence and crime; (iv) changes in social trust and trust in local institutions.

\subsubsection{Alternative Explanation I - Proximity of Preferences to the Tuareg Rebels}

One of the alternative explanations for our main result might be that respondents living closer to the border with Azawad have stronger ethnic or political proximity to the rebellious group. So once that group is in an active conflict with the state, these residents choose to identify less with the state not because of the observed state weakness, but because they sympathize with the rebellious group.

We test this set of explanations in Table 3. To test explanations based on ethnic proximity, Column II of Table 3 omits all respondents who belonged to the Azawad's two largest ethnic groups (Sonrhai (56\%) and Arabs (13\%)). ${ }^{13}$ Additionally, in Column III we omit all respondents whose ethnicity constituted more than $2 \%$ of the Azawad's residents. ${ }^{14}$ All subsamples yield similar estimates, suggesting that people in non-conflict areas unlikely favored rebels on the basis of ethnicity. ${ }^{15}$

Table 3: Alternative explanations: Sympathy toward rebels

\begin{tabular}{|c|c|c|c|c|c|}
\hline & I & II & III & IV & V \\
\hline & \multicolumn{5}{|c|}{ Dependent variable: National identity } \\
\hline Sample & Baseline & $\begin{array}{l}\text { w/o main } \\
\text { Azawad' } \\
\text { ethnicities }\end{array}$ & $\begin{array}{c}\text { w/o all } \\
\text { Azawad' } \\
\text { ethnicities }\end{array}$ & $\begin{array}{l}\text { w/o 10th } \\
\text { percentile of } \\
\text { similarity }\end{array}$ & $\begin{array}{c}\text { w/o } 25 \text { th } \\
\text { percentile of } \\
\text { similarity }\end{array}$ \\
\hline After civil war (2012) & $\begin{array}{c}0.393 * * * \\
(0.038)\end{array}$ & $\begin{array}{c}0.401 * * * \\
(0.038)\end{array}$ & $\begin{array}{c}0.399 * * * \\
(0.038)\end{array}$ & $\begin{array}{c}0.488 * * * \\
(0.064)\end{array}$ & $\begin{array}{c}0.470 * * * \\
(0.072)\end{array}$ \\
\hline $\begin{array}{l}\text { Inv. distance to Azavad } \\
\text { x } 2012\end{array}$ & $\begin{array}{c}-0.203 * \\
(0.109)\end{array}$ & $\begin{array}{c}-0.243 * * \\
(0.111)\end{array}$ & $\begin{array}{c}-0.237 * * \\
(0.112)\end{array}$ & $\begin{array}{c}-0.246^{*} \\
(0.126)\end{array}$ & $\begin{array}{c}-0.302 * \\
(0.166)\end{array}$ \\
\hline Inv. distance to Azavad & $\begin{array}{l}0.165^{*} \\
(0.097)\end{array}$ & $\begin{array}{l}0.192 * * \\
(0.096)\end{array}$ & $\begin{array}{l}0.184^{*} \\
(0.097)\end{array}$ & $\begin{array}{c}0.269 * * \\
(0.118)\end{array}$ & $\begin{array}{l}0.245^{*} \\
(0.140)\end{array}$ \\
\hline$\delta_{\mathrm{s} 1}-\delta_{\mathrm{s} 2}=0, \mathrm{p}$-value & & 0.449 & 0.530 & 0.718 & 0.475 \\
\hline R-squared & 0.185 & 0.183 & 0.183 & 0.103 & 0.100 \\
\hline Observations & 3,141 & 3,070 & 3,062 & 1,934 & 1,691 \\
\hline
\end{tabular}

Notes: All columns include constant and regional fixed effects. The following variables are included as controls: age, age squared, gender dummy, urban dummy, religion dummies (Christians, Muslim or traditional beliefs), dummy personal living conditions, dummy for unemployment, dummies for secondary and tertiary education, dummy for daily access to news, and wealth index. Robust clustered-by-geographical location standard errors are in parentheses. 247 clusters. ${ }^{* * *} \mathrm{p}<0.01,{ }^{* *} \mathrm{p}<0.05,{ }^{*} \mathrm{p}<0.1$

\footnotetext{
${ }^{13}$ Tuaregs (that we always omit) represent $23 \%$ of the Azawad's respondents.

${ }^{14}$ In addition to Sonrhai and Arabs we exclude respondents belonging to Bella (3\%) and Hausa (3\%) ethnolinguistic groups.

${ }^{15}$ Another interesting placebo here would be to see what the effect of the conflict is on Azawad itself; if it is similar to that in border areas, we cannot so readily attribute the finding to simply observing civil conflict as a signal of state weakness. However, Afrobarometer did not collect data there during the 5th round.
} 
To rule out the explanations based on political proximity, for every respondent (both Tuaregs and non-Tuaregs), we calculate their propensity of being a Tuareg using the set of political issues that are most salient for the actual Tuaregs. Specifically, we use the questions on (i) whether people should pay taxes; (ii) whether people should obey laws; (iii) whether the respondent is afraid of political violence; (iv) the respondent's change in living conditions; (v) the importance of religion. Then, in Columns IV and V, we omit those respondents that are in the 25th and 10th percentile of their propensity scores. All resulting estimates are not different from our main specification.

\subsubsection{Alternative Explanation II - Atrocities of the State}

Another alternative explanation is related to state atrocities. Respondents may observe actions of the Malian government in the rebellious areas that they dislike, for example, intensive violence or treatment of refugees. That would explain direct dissatisfaction with the nation-state. ${ }^{16}$ While such data are not available, we use a set of Afrobarometer's questions that indirectly tell us about satisfaction with the government's activity that can be influenced by these atrocities. ${ }^{17}$

In Columns II to VI of Table 4 we include indicator variables for the following questions "fear of politically motivated violence [against the respondent]," "people are treated unequally," "[R's] ethnic group is treated unequally," "president often ignores laws," and "officials are often remain unpunished." We also control for the location of police and army at the respondent's location in Columns VII and VIII. For the exception of a dummy for having an army outpost in the location (Columns VIII), none of these controls appear to be significant, and the coefficient of interest remains unchanged, suggesting that this explanation unlikely drives our results.

\subsubsection{Alternative Explanation III — Public Goods Provision and Violence}

Economic Conditions Another potential alternative explanation is about effectiveness of the state in providing public goods and services. If people's economic conditions deteriorate as a result of a weak state, they would be less likely to accept national identity because they would expect fewer benefits from the nation-state. To show that this mechanism is unlikely to explain our results, we perform a series of placebo tests by estimating our difference-in-differences specification (1), but with economic conditions as dependent variables. ${ }^{18}$

Table 5 contains the results. The interaction term of distance to Azawad and year after insurgency is insignificant for both, the perception of the country's economic performance (Column I),

\footnotetext{
${ }^{16}$ In addition, media consumption could be providing people with more information on atrocities committed by the state during the conflict, and that could directly lower support for the nation.

${ }^{17}$ Some variables are not available for the third wave of Afrobarometer, and we show the baseline specification in Column I estimated using only the fourth and the fifth Afrobarometer waves.

${ }^{18}$ Of course, the deterioration of economic conditions might cause a decline in identification with the nation state because it might signal a weakness of the state, which is consistent with our theory. But because it is difficult to distinguish this mechanism from a more direct mechanism (decreasing the expected utility from goods and services delivered from the state) we choose to show a set of results that demonstrates that this factor is unlikely to be correlated with the national identity anyway.
} 


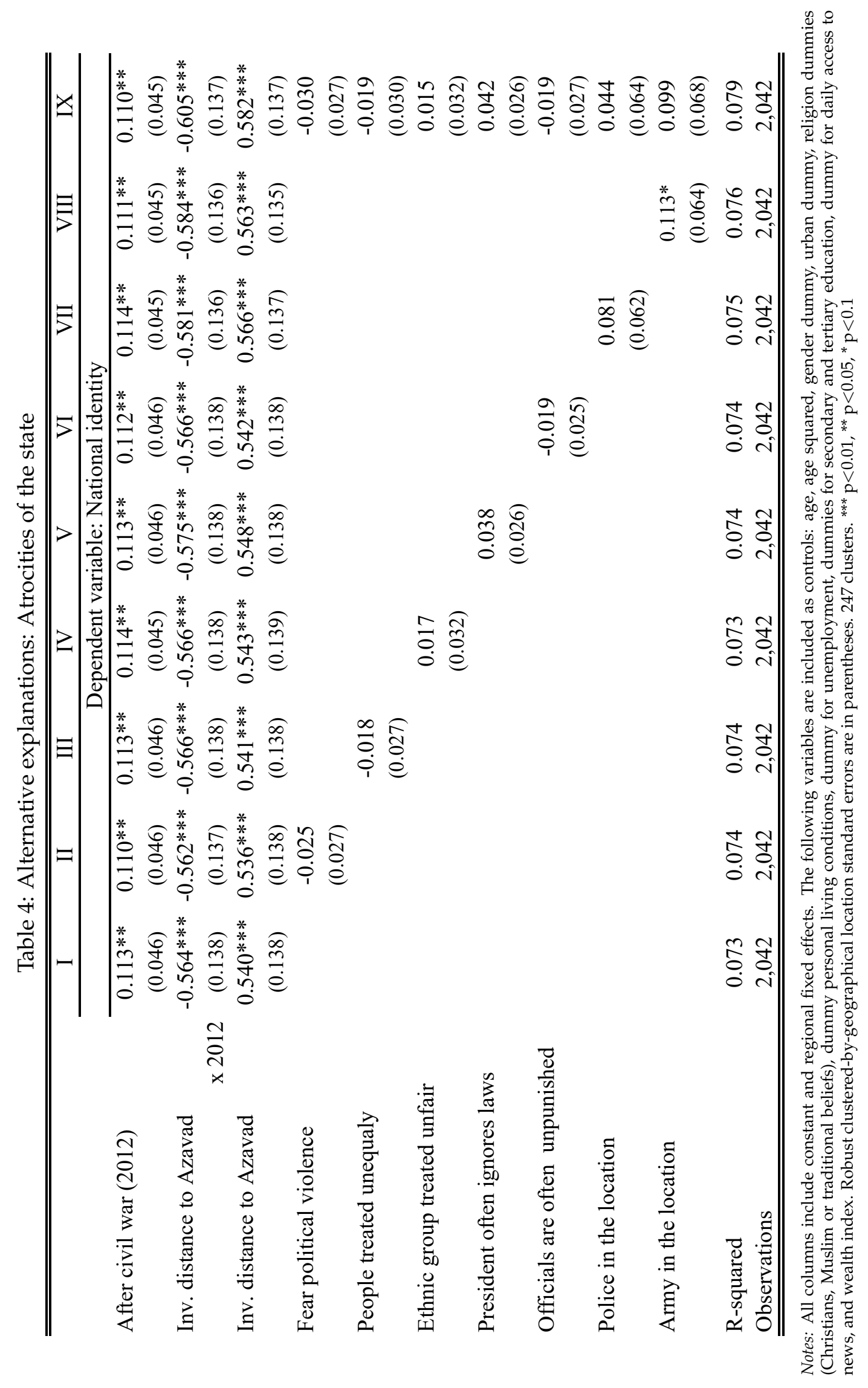


and for the personal living conditions (Column II). If one would think that people reject their identity when there is an adverse shock to their economic conditions, then, since we find no significant coefficients, our results hold. In addition, we control for personal living conditions, income, and employment status in all specifications throughout the paper.

Violence and Crime If people feel danger because of the insurgency the effect on national identity would be mechanical: scared people not protected by the state would revert to their ethnic identities or support rebels. Columns III and IV of Table 5 test whether respondent's house was robbed or if she ever experienced violence. Both coefficients are positive, in line with our expectations, but insignificant, suggesting that crime doesn't drive our results.

Table 5: Alternative explanations: Public goods, economic conditions, and crime

\begin{tabular}{|c|c|c|c|c|c|c|c|}
\hline & $\mathrm{I}$ & II & III & IV & $\mathrm{V}$ & $\mathrm{VI}$ & VII \\
\hline & \multicolumn{7}{|c|}{ Dependent variable: } \\
\hline & $\begin{array}{l}\text { Country's } \\
\text { economic } \\
\text { condition }\end{array}$ & $\begin{array}{l}\text { Personal } \\
\text { economic } \\
\text { condition }\end{array}$ & Home robbed & $\begin{array}{c}\text { Ever } \\
\text { experienced } \\
\text { violence }\end{array}$ & $\begin{array}{l}\text { No medical } \\
\text { care }\end{array}$ & No water & No electricity \\
\hline After civil war (2012) & $\begin{array}{c}0.370 * * * \\
(0.041)\end{array}$ & $\begin{array}{l}-0.000 \\
(0.000)\end{array}$ & $\begin{array}{l}-0.104 \\
(0.068)\end{array}$ & $\begin{array}{c}-0.015^{* *} \\
(0.007)\end{array}$ & $\begin{array}{c}0.001 \\
(0.040)\end{array}$ & $\begin{array}{c}0.043 \\
(0.040)\end{array}$ & $\begin{array}{l}-0.001 \\
(0.019)\end{array}$ \\
\hline $\begin{array}{l}\text { Inv. distance to Azavad } \\
\text { x } 2012\end{array}$ & $\begin{array}{l}-0.133 \\
(0.119)\end{array}$ & $\begin{array}{c}0.000 \\
(0.000)\end{array}$ & $\begin{array}{c}0.226 \\
(0.162)\end{array}$ & $\begin{array}{c}0.046 \\
(0.029)\end{array}$ & $\begin{array}{c}0.014 \\
(0.104)\end{array}$ & $\begin{array}{l}-0.027 \\
(0.119)\end{array}$ & $\begin{array}{c}0.070 \\
(0.065)\end{array}$ \\
\hline Inv. distance to Azavad & $\begin{array}{c}0.073 \\
(0.107)\end{array}$ & $\begin{array}{l}-0.000 \\
(0.000)\end{array}$ & $\begin{array}{c}-0.344 * * \\
(0.164)\end{array}$ & $\begin{array}{l}-0.051 * \\
(0.028)\end{array}$ & $\begin{array}{l}-0.118 \\
(0.108)\end{array}$ & $\begin{array}{c}0.083 \\
(0.118)\end{array}$ & $\begin{array}{l}-0.068 \\
(0.059)\end{array}$ \\
\hline $\begin{array}{l}\text { R-squared } \\
\text { Observations }\end{array}$ & $\begin{array}{l}0.156 \\
3,141\end{array}$ & $\begin{array}{l}1.000 \\
3,141\end{array}$ & $\begin{array}{l}0.050 \\
2,042\end{array}$ & $\begin{array}{l}0.019 \\
2,042\end{array}$ & $\begin{array}{l}0.072 \\
3,141\end{array}$ & $\begin{array}{l}0.059 \\
3,141\end{array}$ & $\begin{array}{l}0.058 \\
2,042\end{array}$ \\
\hline
\end{tabular}

Notes: All columns include constant and regional fixed effects. The following variables are included as controls: age, age squared, gender dummy, urban dummy, religion dummies (Christians, Muslim or traditional beliefs), dummy personal living conditions, dummy for unemployment, dummies for secondary and tertiary education, dummy for daily access to news, and wealth index. Robust clustered-by-geographical location standard errors are in parentheses. 247 clusters. ${ }^{* * *} \mathrm{p}<0.01,{ }^{* *} \mathrm{p}<0.05,{ }^{*} \mathrm{p}<0.1$

Public-Goods Provision If individuals in an exposed area receive fewer benefits from national identity, it could be because their access to ethnic patronage networks and government services generally is disrupted by the conflict, not because they have better information about the state's weakness. If one of the government's main responsibilities - providing public goods was interrupted in the affected regions, it could cause people to revert from their national identity either as a response to the Malian government's failure to provide public goods or as they began to expect decreased utility from accepting national identity of their weak state. Thus, we check whether respondents experienced problems with getting most basic public goods and services: medical care, water, or electricity. We present coefficients of the corresponding regressions in Columns V-VII of Table 5. Neither of them is significant, thus supporting our findings. These results also in line with Gottlieb (2016) who documented that Malians do not expect much from the politicians and public officials, and parties often collude to protect their opportunities for rentsseeking from voters which also leads to poor public-goods provision (Gottlieb (2015)). 


\subsubsection{Alternative Explanation IV - Trust}

Rohner, Thoenig and Zilibotti (2013) show that insurgency in Uganda affected salience of ethnic identity through changes in trust. To test whether our results are channeled through trust to community members or local institutions in Columns II-V of Table 6 we add controls for various measures of trust. The coefficient of interest remains unchanged (see Column I for comparison). Results also hold when we include all measures of trust in Column VI. Thus, our results are unlikely to be mediated by the trust.

Table 6: Alternative explanations: Trust

\begin{tabular}{|c|c|c|c|c|c|c|}
\hline & $\mathrm{I}$ & II & III & IV & $\mathrm{V}$ & VI \\
\hline & \multicolumn{6}{|c|}{ Dependent variable: National identity } \\
\hline After civil war (2012) & $\begin{array}{c}0.419 * * * \\
(0.037)\end{array}$ & $\begin{array}{c}0.416^{* * *} \\
(0.037)\end{array}$ & $\begin{array}{c}0.418 * * * \\
(0.037)\end{array}$ & $\begin{array}{c}0.422 * * * \\
(0.037)\end{array}$ & $\begin{array}{c}0.414 * * * \\
(0.038)\end{array}$ & $\begin{array}{c}0.419 * * * \\
(0.039)\end{array}$ \\
\hline $\begin{array}{l}\text { Inv. distance to Azavad } \\
\qquad x 2012\end{array}$ & $\begin{array}{c}-0.391 * * * \\
(0.097)\end{array}$ & $\begin{array}{c}-0.405 * * * \\
(0.098)\end{array}$ & $\begin{array}{c}-0.389 * * * \\
(0.096)\end{array}$ & $\begin{array}{c}-0.384 * * * \\
(0.099)\end{array}$ & $\begin{array}{c}-0.382 * * * \\
(0.097)\end{array}$ & $\begin{array}{c}-0.401 * * * \\
(0.099)\end{array}$ \\
\hline Inv. distance to Azavad & $\begin{array}{c}0.349 * * * \\
(0.094)\end{array}$ & $\begin{array}{c}0.343 * * * \\
(0.094)\end{array}$ & $\begin{array}{c}0.346^{* * *} \\
(0.093)\end{array}$ & $\begin{array}{c}0.341 * * * \\
(0.096)\end{array}$ & $\begin{array}{c}0.334 * * * \\
(0.095)\end{array}$ & $\begin{array}{c}0.330 * * * \\
(0.096)\end{array}$ \\
\hline Trust to relatives & & $\begin{array}{c}0.023 * * \\
(0.011)\end{array}$ & & & & $\begin{array}{l}0.026^{*} \\
(0.013)\end{array}$ \\
\hline Trust to neighbors & & & $\begin{array}{c}0.003 \\
(0.009)\end{array}$ & & & $\begin{array}{l}-0.011 \\
(0.012)\end{array}$ \\
\hline Trust to strangers & & & & $\begin{array}{c}0.009 \\
(0.008)\end{array}$ & & $\begin{array}{c}0.009 \\
(0.010)\end{array}$ \\
\hline Trust to local government & & & & & $\begin{array}{l}-0.000 \\
(0.009)\end{array}$ & $\begin{array}{l}-0.001 \\
(0.009)\end{array}$ \\
\hline R-squared & 0.169 & 0.170 & 0.170 & 0.170 & 0.169 & 0.171 \\
\hline Observations & 3,151 & 3,150 & 3,144 & 3,131 & 3,066 & 3,050 \\
\hline
\end{tabular}

Notes: All columns include constant and regional fixed effects. The following variables are included as controls: age, age squared, gender dummy, urban dummy, religion dummies (Christians, Muslim or traditional beliefs), dummy personal living conditions, dummy for unemployment, dummies for secondary and tertiary education, dummy for daily access to news, and wealth index. Robust clustered-by-geographical location standard errors are in parentheses. 247 clusters. ${ }^{* * *} \mathrm{p}<0.01,{ }^{* *} \mathrm{p}<0.05,{ }^{*} \mathrm{p}<0.1$

\subsection{Subsample Analysis}

In case our results are driven by a subsample, we analyze the sensitivity and heterogeneity of our results in Table 7, with Column I reporting the baseline specification from Table 1 for comparison.

If rural respondents enjoyed public goods and other amenities less than their urban counterparts, they may be less attached to national identity than urban dwellers. As is evident from Columns II and III, respondents living in rural and urban areas had similar reactions to the insurgency: both coefficients are similar to the one in Column I. The magnitude of the coefficient for the urban subsample is larger than for the rural subsample; however, coefficients do not differ from each other statistically ( $\mathrm{p}$-value $=0.44)$. 
As Tuaregs are predominantly Muslim, in Columns IV and V, we report results for the subsamples of Muslim and non-Muslim respondents, respectively. Here, other Muslims could be more sympathetic to the Tuareg rebels if they sympathize as brothers-in-faith or, less supportive if they consider them traitors. While the coefficient of the interaction is larger for the sample of non-Muslims, the coefficients are also not statistically different from each other ( $\mathrm{p}$-value $=0.22$ ).

Table 7: Civil conflict and national identity: Subsample analysis

\begin{tabular}{|c|c|c|c|c|c|c|c|}
\hline & $\mathrm{I}$ & II & III & IV & $\mathrm{V}$ & VI & VII \\
\hline & \multicolumn{7}{|c|}{ Dependent variable: National identity } \\
\hline Sample & Baseline & Rural & Urban & Muslim & $\begin{array}{l}\text { Non- } \\
\text { Muslim }\end{array}$ & Minorities & Majorities \\
\hline After civil war (2012) & $\begin{array}{l}0.645 * * * \\
(0.117)\end{array}$ & $\begin{array}{c}0.806 * * * \\
(0.139)\end{array}$ & $\begin{array}{l}0.610 * * \\
(0.281)\end{array}$ & $\begin{array}{c}0.692 * * * \\
(0.130)\end{array}$ & $\begin{array}{c}0.336 \\
(0.391)\end{array}$ & $\begin{array}{l}0.756 * * * \\
(0.204)\end{array}$ & $\begin{array}{l}0.574 * * * \\
(0.145)\end{array}$ \\
\hline $\begin{array}{l}\text { Inv. distance to Azavad } \\
\text { x } 2012\end{array}$ & $\begin{array}{c}-0.369 * * * \\
(0.099)\end{array}$ & $\begin{array}{c}-0.266 * * \\
(0.109)\end{array}$ & $\begin{array}{c}-0.482 * \\
(0.268)\end{array}$ & $\begin{array}{c}-0.368 * * * \\
(0.105)\end{array}$ & $\begin{array}{l}-1.195 * \\
(0.718)\end{array}$ & $\begin{array}{c}-0.343 * \\
(0.184)\end{array}$ & $\begin{array}{c}-0.309 * * \\
(0.141)\end{array}$ \\
\hline Inv. distance to Azavad & $\begin{array}{l}0.293 * * * \\
(0.084)\end{array}$ & $\begin{array}{l}0.251 * * \\
(0.106)\end{array}$ & $\begin{array}{c}0.353 \\
(0.242)\end{array}$ & $\begin{array}{l}0.291 * * * \\
(0.085)\end{array}$ & $\begin{array}{l}1.124 \\
(0.693)\end{array}$ & $\begin{array}{c}0.346 * * \\
(0.157)\end{array}$ & $\begin{array}{l}0.208 * * \\
(0.100)\end{array}$ \\
\hline$\delta_{\mathrm{s} 1}-\delta_{\mathrm{s} 2}=0, \mathrm{p}$-value & & \multicolumn{2}{|c|}{0.437} & \multicolumn{2}{|c|}{0.215} & \multicolumn{2}{|c|}{0.895} \\
\hline R-squared & 0.210 & 0.229 & 0.231 & 0.217 & 0.324 & 0.247 & 0.202 \\
\hline Observations & 3,135 & 2,284 & 846 & 2,854 & 280 & 1,076 & 2,055 \\
\hline
\end{tabular}

Notes: All columns include constant and regional fixed effects. The following variables are included as controls: age, age squared, gender dummy, urban dummy, religion dummies (Christians, Muslim or traditional beliefs), dummy for personal living conditions, dummy for unemployment, dummies for secondary and tertiary education, dummy for daily access to news, and wealth index. Robust clustered-by-geographical location standard errors are in parentheses. 247 clusters. ${ }^{* * *} \mathrm{p}<0.01,{ }^{* *} \mathrm{p}<0.05,{ }^{*} \mathrm{p}<0.1$

Finally, we check whether the results differ for subsamples of Malian ethnic groups. We find that majority ethnic groups, despite the insurgency, were less likely to abandon national identity because their interests were more likely to be represented by the government. ${ }^{19}$ As Mali is ethnically diverse, we distinguish the three largest broad ethnic groups in the Afrobarometer data, which constitute approximately 65 percent of the total population. ${ }^{20} \mathrm{We}$ assign an indicator variable equal to one if the respondents belong to those ethnic groups, and zero otherwise. We present results for the subsamples of respondents belonging to minority and majority ethnic groups in Columns VI and VII. Indeed, for respondents from the ethnic majority exposed to insurgency, their national identification decreases by 31.5 percentage-points per 100 kilometers, while the effect on minority respondents is slightly larger (38.6 percentage-points). The difference is also statistically insignificant. We study this issue further in Appendix C.3, where we report results for the exact matching on a set of demographic parameters and ethnicities. We demonstrate that respondents living within 250 kilometers from the Azawad's border (i.e., in Mopti) are less likely to identify as Malian. Our exact matching results are almost identical to our baseline results and are robust to different types of matching procedures. While the last two columns demonstrate that there is some heterogeneity in the size of the ethnic groups, the effect of civil conflict on national identity

\footnotetext{
${ }^{19}$ Mali was considered a democratic state (for example, with a preconflict polity score of 7 from Polity IV).

${ }^{20}$ Malinke/Bambara (41\%), Peulh/Fulfulde (15\%), and Soninke/Sarakoll (10\%).
} 
is still significant for all population groups.

\section{Mechanism: Media Consumption and the Perception of State's Weak- ness}

How does the construction of national identity become possible, and what are its main impediments? In this section, we offer a formal model of identity choice that centers on information and coordination. In the spirit of the definition of state as an organization that controls violence, we propose a new mechanism: information about civil conflict can break up the successful coordination of identities. Then we empirically show that locations that had more precise information about the state's weakness (i.e., respondents had exposure to media), conditional on the distance to the conflict zone, experienced higher decline in national identity. Consistent with our hypothesis that the effect goes through the perception of the state's weakness, we also document that respondents located closer to the conflict zone experienced larger a decline in trust in national leader, and that variation strongly predict changes in national identity.

\subsection{National Identity as a Coordination Problem}

We use the global games approach proposed in Carlsson and Van Damme (1993) and popularized in Morris and Shin $(1998,2004)$ to model the choice of identity by the residents of a country exposed to a civil conflict. We view the choice of identity as a coordination problem. Each citizen of a multiethnic state has a choice: to keep their ethnic identity (status quo) or embrace national identity with potential benefits, in case enough people decide to support the national identity. ${ }^{21}$ While in reality, the identity can be nonbinary and people can keep several identities at the same time, we theorize that one of those identities can be more salient than others and we try to understand their relative salience. Each citizen has their own private estimate of the benefits from accepting national identity and each citizen observes a public signal about the strength of the state. Because the viability of national identity is anchored in the existence of a well-functioning state, threats to state institutions break up that coordination and thus erode national identity. If the state becomes observably weaker, the expected benefit from accepting the national identity decreases. It is important to note that, while some other theories imply slow, often multi-generational, process of identity formation (Laitin (1998)), our model explains more rapid changes. ${ }^{22}$

The payoffs from having a national identity depend on how many other people also choose to prioritize national identity, and these payoffs are potentially larger than the payoffs from ethnic identity. This is why the information about insurgent activities has a twofold effect: it directly de-

\footnotetext{
${ }^{21}$ Here, we do not assume that ethnic identity is primordial in any sense, just that the construction of ethnic identities had preceded the nation-building efforts by postcolonial governments.

${ }^{22}$ While many of the theories of state capacity focus on the ability of state to collect taxes and build infrastructure (Besley and Persson (2009) and Acemoglu, Moscona and Robinson (2016)), it is not uncommon for relatively capable states to disintegrate into civil wars quickly. By emphasizing a coordination nature of national identity, we explain the previously underappreciated aspects of state capacity.
} 
creases the utility of associating oneself with the state and it also inhibits the coordination around a national identity because it influences higher-order beliefs about whether other people in a society are likely to prefer national identity. We formalize this intuition in Section A. The model produces a specific testable prediction: people's self-identification with the state goes down if the state becomes observably weaker. This effect is the largest where the information about state weakness is the most precise.

\subsection{Heterogeneous Effects with Media/Community Exposure}

Here, we provide suggestive evidence for the coordination mechanism by showing that civil conflict decrease the demand for national identity through the channel of information about state's weakness. That is, more informed respondents are less likely to self identify with a nation even conditional on the distance to the conflict zone. While we do not observe the extent to which people are informed about the insurgency, we do observe their self-reported media consumption. We estimate the same equation as in 1 , but we add an interaction of the $P O S T_{t} \times$ Distance to Azawad $_{c}$ with the media consumption ${ }_{i(c) t}$. We measure this variable as an indicator variable equal to one if an individual receives any news through newspaper or television every day, and zero otherwise. Eventually, this specification is difference-in-difference-in-difference; we also add interactions for $\mathrm{POST}_{t} \times$ media consumption $_{i(c) t}$, and Distance to Azawad $_{c} \times \operatorname{media}_{\text {consumption }}(\mathrm{cc}) t$

Table 8: Civil conflict and national identity: Information on state's "weakness"

\begin{tabular}{|c|c|c|c|c|}
\hline & $\mathrm{I}$ & II & III & IV \\
\hline & \multicolumn{4}{|c|}{ Dependent variable: National identity } \\
\hline & \multicolumn{2}{|c|}{ Media exposure } & \multicolumn{2}{|c|}{ Member in community group } \\
\hline After civil war (2012) & $\begin{array}{c}0.314 \\
(0.225)\end{array}$ & $\begin{array}{l}0.356 \\
(0.206)\end{array}$ & $\begin{array}{l}0.458 * * \\
(0.020)\end{array}$ & $\begin{array}{l}0.435^{*} \\
(0.036)\end{array}$ \\
\hline Inv. distance to Azavad x 2012 & $\begin{array}{l}-0.126 \\
(0.091)\end{array}$ & $\begin{array}{l}-0.124 \\
(0.085)\end{array}$ & $\begin{array}{l}-0.273 \\
(0.055)\end{array}$ & $\begin{array}{l}-0.250 \\
(0.102)\end{array}$ \\
\hline Inv. distance to Azavad & $\begin{array}{c}0.199 \\
(0.091)\end{array}$ & $\begin{array}{c}0.209 \\
(0.091)\end{array}$ & $\begin{array}{l}0.310 \\
(0.105)\end{array}$ & $\begin{array}{c}0.287 \\
(0.143)\end{array}$ \\
\hline $\begin{array}{l}\text { Inv. distance to Azavad x } 2012 \\
\qquad \times \text { Characteristic }\end{array}$ & $\begin{array}{r}-0.164 * \\
(0.049)\end{array}$ & $\begin{array}{l}-0.162 * \\
(0.053)\end{array}$ & $\begin{array}{l}-0.272 * \\
(0.037)\end{array}$ & $\begin{array}{l}-0.296 \\
(0.096)\end{array}$ \\
\hline $\begin{array}{l}\text { Inv. distance to Azavad } \\
\qquad \mathrm{x} \text { Characteristic }\end{array}$ & $\begin{array}{c}0.014 \\
(0.032)\end{array}$ & $\begin{array}{l}-0.009 \\
(0.039)\end{array}$ & $\begin{array}{l}-0.002 \\
(0.018)\end{array}$ & $\begin{array}{c}0.006 \\
(0.055)\end{array}$ \\
\hline 2012 x Characteristic & $\begin{array}{l}-0.036 \\
(0.039)\end{array}$ & $\begin{array}{l}-0.047 \\
(0.033)\end{array}$ & $\begin{array}{l}0.187 * * \\
(0.010)\end{array}$ & $\begin{array}{l}0.199^{*} \\
(0.027)\end{array}$ \\
\hline $\begin{array}{l}\text { Characteristic: } \\
\text { Media / Member in community group }\end{array}$ & $\begin{array}{c}0.000 \\
(0.025)\end{array}$ & $\begin{array}{l}-0.014 \\
(0.024)\end{array}$ & $\begin{array}{l}-0.046 \\
(0.017)\end{array}$ & $\begin{array}{c}0.000 \\
(0.012)\end{array}$ \\
\hline $\begin{array}{l}\text { Controls } \\
\text { R-squared } \\
\text { Observations }\end{array}$ & $\begin{array}{l}0.176 \\
3,142\end{array}$ & $\begin{array}{c}X \\
0.186 \\
3,142\end{array}$ & $\begin{array}{l}0.086 \\
2,044\end{array}$ & $\begin{array}{c}X \\
0.099 \\
2,044\end{array}$ \\
\hline
\end{tabular}

Notes: All columns include constant and regional fixed effects. The following variables are included as controls: age, age squared, gender dummy, urban dummy, religion dummies (Christians, Muslim or traditional beliefs), dummy personal living conditions, dummy for unemployment, dummies for secondary and tertiary education, dummy for access to news, and wealth index. Robust clusteredby-geographical location standard errors are in parentheses. 247 clusters. ${ }^{* * *} p<0.01,{ }^{* *} p<0.05,{ }^{*} p<0.1$ 
The results are presented in Table 8, where Columns I and II contain results for daily news consumption. Column I shows a specification without any controls, while Column II contains a specification with the full set of controls. As we can see, the interaction between distance-to-Azawad and year after insurgency, and their interaction with daily media consumption are negative. The effect is driven through the respondents that are more exposed to media. This suggests that the effect of insurgency is larger for those individuals who have more information about the weakness of the regime in line with the model where the probability that a person accepting national identity is decreasing with a public signal about the weakness of the state.

Finally, in Columns III and IV, we demonstrate that the decline in national identity is stronger among those respondents that are active members of local voluntary associations or community groups. As these people gather together they are more likely to exchange their opinion about the conflict and state capacity with their friends.

The model's key assumption is that conflict does not impact the result except through giving people information about the strength/stability of the national government. While these results are not causal, as media consumption is endogenous to interest in the conflict (and could be correlated with baseline sympathy for the rebels), they say that more informed respondents conditional on the same distance to Azawad had lower self-identification with the nation than less informed respondents. This our model's result about information being the primary mechanism by which conflict alters payoffs and making individuals be less interested in choosing nation identity (building a nation-state).

\subsection{Perception of the State's Weakness as the Channel}

The impact of the distance to the conflict zone on national identity can plausibly have two possibly overlapping types of channels - national and local. People might become less supportive of their local leaders (who might be unable to shield their communities from the effect of civil war), or they might lose faith in the national leadership. They also might have both types of reactions: trust in local leadership and in the national leadership might go down. To explore these predictions we estimate a regression with trust in national leadership and trust in local leadership as dependent variables, and the distance to the conflict zone (Azawad) as an independent variable, and a set of baseline controls. Table 9 presents the results. We find no association between the distance to Azawad and post-conflict change in trust in local leadership (Column I), a nonsignificant negative effect on trust to parliament (Column II), and a strong negative association between the distance to Azawad and post-conflict change in trust in national leader (Column III). This result supports the hypothesis about the channel of the effect being the national one and not the local one. 
Table 9: Civil conflict and national identity: Distance to Azawad and trust

\begin{tabular}{|c|c|c|c|c|c|c|c|}
\hline & $\overline{\mathrm{I}}$ & II & III & IV & $\overline{\mathrm{V}}$ & $\overline{\mathrm{VI}}$ & VII \\
\hline & \multicolumn{7}{|c|}{ Dependent variable: } \\
\hline & $\begin{array}{l}\text { Trust to local } \\
\text { government }\end{array}$ & $\begin{array}{c}\text { Trust to } \\
\text { parliament }\end{array}$ & $\begin{array}{c}\text { Trust to } \\
\text { national leader }\end{array}$ & & Nationa & & \\
\hline After civil war (2012) & $\begin{array}{l}-0.078 \\
(0.104)\end{array}$ & $\begin{array}{c}-0.363^{* * *} \\
(0.092)\end{array}$ & $\begin{array}{c}1.091^{* * *} \\
(0.067)\end{array}$ & $\begin{array}{l}-0.015 \\
(0.027)\end{array}$ & $\begin{array}{l}-0.013 \\
(0.029)\end{array}$ & $\begin{array}{l}-0.039 \\
(0.028)\end{array}$ & $\begin{array}{c}-0.062 * * \\
(0.030)\end{array}$ \\
\hline $\begin{array}{l}\text { Inv. distance to Azavad } \\
\text { x } 2012\end{array}$ & $\begin{array}{l}-0.075 \\
(0.312)\end{array}$ & $\begin{array}{l}-0.262 \\
(0.257)\end{array}$ & $\begin{array}{c}-0.649 * * * \\
(0.140)\end{array}$ & & & & \\
\hline Inv. distance to Azavad & $\begin{array}{c}0.092 \\
(0.318)\end{array}$ & $\begin{array}{l}0.072 \\
(0.241)\end{array}$ & $\begin{array}{c}0.664 * * * \\
(0.130)\end{array}$ & & & & \\
\hline PCA trust to locals & & & & $\begin{array}{l}-0.004 \\
(0.009)\end{array}$ & & & $\begin{array}{l}-0.002 \\
(0.010)\end{array}$ \\
\hline Trust to parliament & & & & & $\begin{array}{l}-0.017^{*} \\
(0.010)\end{array}$ & & $\begin{array}{c}-0.031 * * * \\
(0.010)\end{array}$ \\
\hline Trust to local government & & & & & & $\begin{array}{c}0.024 * * \\
(0.010)\end{array}$ & $\begin{array}{c}0.043 * * * \\
(0.010)\end{array}$ \\
\hline R-squared & 0.104 & 0.138 & 0.211 & 0.156 & 0.153 & 0.157 & 0.158 \\
\hline Observations & 3,051 & 2,916 & 3,043 & 3,051 & 2,916 & 3,043 & 2,838 \\
\hline
\end{tabular}

Notes: All columns include constant and regional fixed effects. The following variables are included as controls: age, age squared, gender dummy, urban dummy, religion dummies (Christians, Muslim or traditional beliefs), dummy personal living conditions, dummy for unemployment, dummies for secondary and tertiary education, dummy for access to news, and wealth index. Robust clusteredby-geographical location standard errors are in parentheses. 247 clusters. ${ }^{* * *} \mathrm{p}<0.01,{ }^{* *} \mathrm{p}<0.05,{ }^{*} \mathrm{p}<0.1$

To substantiate the hypothesis further, we explore if the variation in the trust in the national leader explained by the distance from Azawad can also explain the variation in national identity. We follow Dippel et al. (2017) and estimate a two-stage-least-squares (2SLS) regression. The first stage looks as follows:

Trust in national leader $i(c) t=\alpha+\beta$ Distance to Azawad $_{c}+\delta\left(P O S T_{t} \times\right.$ Distance to Azawad $\left._{c}\right)$

$$
+X_{i t}^{\prime} \Gamma+\mu_{r}+\lambda_{t}+\epsilon_{i t}
$$

and the second stage is

$$
N I_{i(c) t}=\alpha+\pi \text { Trust to } \widehat{\text { national }} \text { leader }_{i(c) t}+X_{i t}^{\prime} \Gamma+\mu_{r}+\lambda_{t}+\nu_{i t}
$$

Here, trust in national leader is an endogenous variable that measures the extent of the national channel. The instrument identifies changes in trust in national leader driven by the proximity to the conflict zone. Hence, the results of the baseline specification 1 can be regarded as reduced form results.

Table 10 contain the results. Columns I-III present the second-stage results from increasingly rich variations of the model. We find that the variation in trust in national leader influenced by the proximity to the conflict zone has a strong positive effect in national identity: 10 percentage points increase in trust in national leader is associated with 5.3-6.6 percentage point increase in national 
identity. These results are consistent with the effect of proximity to conflict being mediated by the perception of national leadership.

Table 10: Civil conflict and national identity: IV analysis

\begin{tabular}{|c|c|c|c|}
\hline \multirow[b]{3}{*}{ After civil war (2012) } & $\mathrm{I}$ & II & III \\
\hline & \multicolumn{3}{|c|}{ Dependent variable: National identity } \\
\hline & $\begin{array}{c}-0.502 * * * \\
(0.151)\end{array}$ & $\begin{array}{c}-0.590 * * * \\
(0.209)\end{array}$ & $\begin{array}{c}-0.639 * * * \\
(0.225)\end{array}$ \\
\hline Trust to national leader & $\begin{array}{c}0.527 * * * \\
(0.171)\end{array}$ & $\begin{array}{c}0.655 * * * \\
(0.248)\end{array}$ & $\begin{array}{c}0.604 * * * \\
(0.224)\end{array}$ \\
\hline PCA trust to locals & & $\begin{array}{c}-0.102 * * \\
(0.044)\end{array}$ & $\begin{array}{c}-0.059 * * \\
(0.028)\end{array}$ \\
\hline Trust to parliament & & & $\begin{array}{c}-0.055^{* *} \\
(0.025)\end{array}$ \\
\hline Trust to local government & & & $\begin{array}{c}-0.208 * * * \\
(0.073)\end{array}$ \\
\hline Partial R-squared & 0.004 & 0.003 & 0.004 \\
\hline Kleibergen-Paap F stat. & 13.13 & 8.81 & 11.07 \\
\hline Observations & 3,043 & 3,024 & 2,824 \\
\hline
\end{tabular}

Notes: All columns include constant and regional fixed effects. The following variables are included as controls: age, age squared, gender dummy, urban dummy, religion dummies (Christians, Muslim or traditional beliefs), dummy personal living conditions, dummy for unemployment, dummies for secondary and tertiary education, dummy for access to news, and wealth index. Robust clusteredby-geographical location standard errors are in parentheses. 247 clusters. ${ }^{* * *} p<0.01,{ }^{* *} p<0.05,{ }^{*} p<0.1$

\section{Discussion and Conclusion}

Much of people's political, economic, and social life is organized around the existence of geographically defined sovereign entities. Formation of such sovereign entities - nation-states has been shown to be essential for economic development. Without a capable state, it is nearly impossible to ensure the provision of public goods and services, enforcement of contracts, and national security (Dincecco and Prado (2012) and Acemoglu, Garcia-Jimeno and Robinson (2015)). A number of studies have looked at the problem of nation-building from the perspective of tangible tasks that a state needs to perform, such as education, administration, police, and taxation (Geddes (1994), Besley and Persson (2010), and Soifer (2015)). Those studies help us understand the challenges facing governments of weak states when they try to perform functions that are normally seen as the state's responsibility.

This paper looks at another aspect of state-formation: the degree to which people associate themselves with the nation-state. We show that civil conflicts may erode national identity, even in areas that are not directly experiencing combat. Previous literature has established that civil conflict can adversely affect national identity of ethnic groups directly involved in the fight through the corrosion of between-group social capital (Rohner, Thoenig and Zilibotti (2013)). The effect of 
conflict on groups that do not live in the conflict zones and are not members of the rebellious factions remained an open question until now. In this paper, we used a quasi-exogenous timing of the most recent instance of Tuareg rebellion in Northern Mali to estimate the effect. In a differencein-difference framework we find that an onset of conflict has led to a significant decrease in national identity, the effect being stronger for those who consumed more local news media. We verified that the effect was not driven by the differential pre-conflict trends, access to public goods, ethnic identification, security environment, or generalized trust. Our preferred explanation is that it is information about the outbreak of the insurgency that influenced people's intrinsic calculations about the benefits of being associated with the state. The fact that the effect is the strongest among consumers of local news is consistent with this mechanism.

We have to make an important note about the external validity of our results. While the quantitative literature often does not differentiate between different types of civil wars, qualitative studies of Africa's recent history provide an informative distinction. For example, Reno (2011) describes the following categories of wars: anti-colonial (such as MPLA-led rebellion in Angola in 1961-74), majority-rule (such as popular movements in minority-ruled Zimbabwe, South Africa, and Namibia), pro-reform rebellions (such as the one led by Rwandan Patriotic Front in 1979-94), warlord rebellions (such as Charles Taylor's insurgency in Liberia in 1989-91), and parochial rebellions (violence in Kenya associated with elections in 2002 and 2007). From the perspective of our hypothesis, each of these type of conflicts might signify state weakness and thus lead to lower national identity (with the possible exception of anti-colonial wars), but the size of the effect might vary. From this perspective, the events in Northern Mali were an example of a parochial rebellion - an attempt to take over a piece of territory by a community allegedly neglected by the current regime. Parochial rebellions should probably have the largest effect on national identity since the outbreak of such rebellion might signify not only current state weakness, but also a long-run absence of governmental involvement in certain geographical areas. The effect of other types of insurgencies might be still negative but smaller in magnitude.

To conclude, some see the construction of national identities as a great accomplishment of African postcolonial development: though African states have arbitrary borders drawn by European colonial powers, in the post-colonial period these imagined borders became a reality, and the African political map has proved remarkably resilient with comparatively few conflicts between states. While this is a serious achievement, one might still wonder why construction of national identity is difficult in some circumstances and not in others, and why this number is not close to 100 percent. Our study suggests that frequent civil conflicts in African countries may erode national identity, thus highlighting a reason why civil conflict is costly for growth and development. 


\section{References}

Acemoglu, Daron, Camilo Garcia-Jimeno, and James A. Robinson. 2015. "State capacity and economic development: A network approach." American Economic Review, 105(8): 2364-2409.

Acemoglu, Daron, Jacob Moscona, and James A. Robinson. 2016. "State capacity and American technology: evidence from the nineteenth century." American Economic Review, 106(5): 61-67.

Alesina, Alberto, and Bryony Reich. 2015. "Nation building." National Bureau of Economic Research.

Alesina, Alberto, Arnaud Devleeschauwer, William Easterly, Sergio Kurlat, and Romain Wacziarg. 2003. "Fractionalization." Journal of Economic growth, 8(2): 155-194.

Alesina, Alberto, Bryony Reich, and Alessandro Riboni. 2017. "Nation-Building, Nationalism and Wars." National Bureau of Economic Research.

Alesina, Alberto, Reza Baqir, and William Easterly. 1999. "Public goods and ethnic divisions." The Quarterly Journal of Economics, 114(4): 1243-1284.

Ananyev, Maxim, and Sergei Guriev. 2018. "Effect of Income on Trust Evidence from the 2009 Economic Crisis in Russia." The Economic Journal.

Anderson, Benedict. 2006. Imagined communities: Reflections on the origin and spread of nationalism. Verso Books.

Bahgat, Karim, Kendra Dupuy, Gudrun Østby, Siri Aas Rustad, Håvard Strand, and Tore Wig. 2018. “Children and Armed Conflict: What Existing Data Can Tell Us." Technical report, PRIO.

Baldwin, Kate, and John D Huber. 2010. "Economic versus cultural differences: Forms of ethnic diversity and public goods provision." American Political Science Review, 104(4): 644-662.

Bauer, Michal, Christopher Blattman, Julie Chytilová, Joseph Henrich, Edward Miguel, and Tamar Mitts. 2016. “Can war foster cooperation?" Journal of Economic Perspectives, 30(3): 249-74.

Becker, Sascha O, and Andrea Ichino. 2002. "Estimation of average treatment effects based on propensity scores." The stata journal, 2(4): 358-377.

Besley, Timothy, and Torsten Persson. 2009. "The origins of state capacity: Property rights, taxation, and politics." American Economic Review, 99(4): 1218-44.

Besley, Timothy, and Torsten Persson. 2010. "State capacity, conflict, and development." Econometrica, 78(1): 1-34.

Bhavnani, Ravi, and Dan Miodownik. 2009. "Ethnic polarization, ethnic salience, and civil war." Journal of Conflict Resolution, 53(1): 30-49.

Bloom, Nicholas, Benn Eifert, Aprajit Mahajan, David McKenzie, and John Roberts. 2013. “Does management matter? Evidence from India." The Quarterly Journal of Economics, 128(1): 1-51.

Braithwaite, Alex, Niheer Dasandi, and David Hudson. 2016. "Does poverty cause conflict? Isolating the causal origins of the conflict trap." Conflict Management and Peace Science, 33(1): 45-66.

Cameron, A Colin, Jonah B Gelbach, and Douglas L Miller. 2008. "Bootstrap-based improvements for inference with clustered errors." The Review of Economics and Statistics, 90(3): 414-427.

Carlsson, Hans, and Eric Van Damme. 1993. "Global games and equilibrium selection." Econometrica: Journal of the Econometric Society, 989-1018.

Carvalho, Jean-Paul. 2017. “Coordination and culture." Economic Theory, 64(3): 449-475.

Cederman, Lars-Erik, and Luc Girardin. 2007. “Beyond fractionalization: Mapping ethnicity onto nationalist insurgencies." American Political science review, 101(1): 173-185.

Collier, Paul, et al. 2003. Breaking the conflict trap: Civil war and development policy. World Bank Publications.

Dell, Melissa, and Pablo Querubin. 2018. "Nation building through foreign intervention: Evidence from discontinuities in military strategies." The Quarterly Journal of Economics, 133(2): 701-764.

Depetris-Chauvin, Emilio, Ruben Durante, and Filipe R Campante. 2018. “Building Nations Through Shared Experiences: Evidence from African Football." National Bureau of Economic Research.

Dincecco, Mark, and Mauricio Prado. 2012. "Warfare, fiscal capacity, and performance." Journal of Economic Growth, 17(3): 171-203.

Dippel, Christian, Robert Gold, Stephan Heblich, and Rodrigo Pinto. 2017. “Instrumental variables and causal mechanisms: Unpacking the effect of trade on workers and voters." National Bureau of Economic Research.

Easterly, William, and Ross Levine. 1997. "Africa's growth tragedy: policies and ethnic divisions." The quarterly journal of economics, 112(4): 1203-1250.

Eifert, Benn, Edward Miguel, and Daniel N Posner. 2010. "Political competition and ethnic identification in Africa." American Journal of Political Science, 54(2): 494-510.

Ekeh, Peter P. 1975. "Colonialism and the two publics in Africa: a theoretical statement." Comparative studies in society and history, 17(01): 91-112.

Geddes, Barbara. 1994. Politician's dilemma: building state capacity in Latin America. Univ of California Press.

Gellner, Ernest, and John Breuilly. 2008. Nations and nationalism. Cornell University Press.

Gilligan, Michael J, Benjamin J Pasquale, and Cyrus Samii. 2014. "Civil war and social cohesion: Lab-in-the-field evidence from Nepal." American Journal of Political Science, 58(3): 604-619. 
Gottlieb, Jessica. 2015. “The logic of party collusion in a democracy: Evidence from Mali." World Politics, 67(1): 1-36.

Gottlieb, Jessica. 2016. “Greater expectations: A field experiment to improve accountability in Mali." American Journal of Political Science, 60(1): 143-157.

Hanlon, W Walker. 2015. "Necessity is the mother of invention: Input supplies and Directed Technical Change." Econometrica, 83(1): 67-100.

Hobsbawm, Eric J. 2012. Nations and nationalism since 1780: Programme, myth, reality. Cambridge University Press.

Imbens, Guido W, and Michal Kolesar. 2016. “Robust standard errors in small samples: Some practical advice." Review of Economics and Statistics, 98(4): 701-712.

Kalyvas, Stathis N. 2008. "Ethnic defection in civil war." Comparative Political Studies, 41(8): 1043-1068.

Kibris, Arzu. 2015. "The conflict trap revisited: Civil conflict and educational achievement." Journal of Conflict Resolution, 59(4): 645-670.

Laitin, David D. 1998. Identity in formation: The Russian-speaking populations in the near abroad. Cornell University Press.

MacKinnon, James G, and Halbert White. 1985. "Some heteroskedasticity-consistent covariance matrix estimators with improved finite sample properties." Journal of econometrics, 29(3): 305-325.

Makarin, Alexey, and Vasily Korovkin. 2018. "Trading with the Enemy: The Impact of Conflict on Trade Transactions in Non-Conflict Areas." Working paper.

Mann, Michael. 2012. The sources of social power: Volume 3, global empires and revolution, 1890-1945. Vol. 3, Cambridge University Press.

Miguel, Edward. 2004. “Tribe or nation? Nation building and public goods in Kenya versus Tanzania." World Politics, 56(03): 328-362.

Morris, Stephen, and Hyun Song Shin. 1998. "Unique equilibrium in a model of self-fulfilling currency attacks." American Economic Review, 587-597.

Morris, Stephen, and Hyun Song Shin. 2004. "Coordination risk and the price of debt." European Economic Review, 48(1): 133-153.

Posner, Daniel N. 2004a. "Measuring ethnic fractionalization in Africa." American journal of political science, 48(4): 849863.

Posner, Daniel N. 2004b. “The political salience of cultural difference: Why Chewas and Tumbukas are allies in Zambia and adversaries in Malawi." American Political Science Review, 98(04): 529-545.

Posner, Daniel N. 2005. Institutions and ethnic politics in Africa. Cambridge University Press.

Reno, William. 2011. Warfare in independent Africa. Vol. 5, Cambridge University Press.

Robinson, Amanda Lea. 2014. "National versus ethnic identification in Africa: Modernization, colonial legacy, and the origins of territorial nationalism." World Politics, 66(04): 709-746.

Rohner, Dominic, Mathias Thoenig, and Fabrizio Zilibotti. 2013. "Seeds of distrust: Conflict in Uganda." Journal of Economic Growth, 18(3): 217-252.

Sambanis, Nicholas, and Moses Shayo. 2013. "Social identification and ethnic conflict." American Political Science Review, 107(2): 294-325.

Sarkees, Meredith Reid, and Frank Whelon Wayman. 2010. Resort to war: a data guide to inter-state, extra-state, intra-state, and non-state wars, 1816-2007. Cq Pr.

Shaw, Scott. 2013. "Fallout in the Sahel: the geographic spread of conflict from Libya to Mali." Canadian Foreign Policy Journal, 19(2): 199-210.

Shayo, Moses. 2009. "A model of social identity with an application to political economy: Nation, class, and redistribution." American Political science review, 103(2): 147-174.

Soifer, Hillel David. 2015. State Building in Latin America. Cambridge University Press.

Welch, Bernard L. 1947. "The generalization ofstudent's' problem when several different population variances are involved." Biometrika, 34(1/2): 28-35. 


\section{Online Appendix}

to

"State Capacity and Demand for Identity:

Evidence from Political Instability in Mali" 


\section{A Model}

The inspiration for our model comes from Peter P. Ekeh's idea of "two publics." Ekeh (1975) asserted that African nations are caught in the duality of loyalties: the first loyalty is to the "primordial public" (Ekeh uses the word "primordial" here for expressive convenience, with full appreciation of the socially constructed nature of many of Sub-Saharan ethno-linguistic groups), and the second one is to the "civic public." This conflict of loyalties shapes many aspects of political and economic development in Africa. Building on this insight, we outline the formal logic of the choice between the two loyalties and demonstrate how incapacity of the state to control violence shifts the balance away from the civic public.

\section{A.1 Setup}

Consider an area with a continuum of agent-residents of a country $(i)$ of the measure one, uniformly distributed over $[0,1]$. We assume that all agents are homogeneous, but that they might belong to different ethnic groups. Agents face a binary choice of whether to accept a national identity or to retain an ethnic identity.

Resident $i$ 's payoff as follows:

$$
u_{i}= \begin{cases}0 & \text { if the agent keeps ethnic identity } \\ \theta+\tau A & \text { if the agent accepts national identity }\end{cases}
$$

where parameter $\theta$ captures the expected net benefit from a strong national state. Here we assume that ethnic identity is the status quo: people have innate preferences for being a part of their "tribe," as did their parents and grandparents. Importantly, we allow "group size benefit" for those who decide to associate themselves with the nation: their payoff depends on $A \in[0,1]$ the total share of agents deciding to associate themselves with the country's nation. An example of such a benefit is an access to credit and urban jobs. It has been documented that in many African nations, ethnicity serves as a vehicle for dispensing patronage. In the case of Zambia, Posner (2005) describes a tendency of ethnic favoritism in hiring. Put succinctly in a Nyanja term "wako ni wako" ("what's yours is yours"). Parameter $\tau>0$ captures the the magnitude of this benefit from the size of agents that who decided to associate themselves with the nation. The value of $\tau$ is common knowledge.

The agents have a diffuse prior distribution of $\theta \in \mathbb{R}$. We assume that citizens receive a common signal $p=\theta+\varepsilon$, where $\varepsilon \sim \mathcal{N}(0, \alpha)$ is the noise. It can be interpreted as imperfect common knowledge about the stability of the government. In addition, each citizen receives an independent private signal $x_{i}=\theta+\xi_{i}$, where $\xi_{i} \sim \mathcal{N}(0, \beta)$ is noise. It represents a personal assessment of the benefits from national identity (in the vein of Carvalho (2017)). People update their private signal with the public one: $\bar{\theta}_{i}=\theta \mid p, x_{i} \sim \mathcal{N}\left(\frac{\alpha x_{i}+\beta p}{\alpha+\beta} ; \frac{\alpha \beta}{\alpha+\beta}\right)$.

\section{A.2 Analysis}

We seek equilibrium in threshold strategies. Agents have two strategies:

$$
a_{i}\left(\bar{\theta}_{i}\right)= \begin{cases}\text { keep ethnic identity } & \text { if } \bar{\theta}_{i} \leq \kappa^{*} \\ \text { accept national identity } & \text { if } \bar{\theta}_{i}>\kappa^{*}\end{cases}
$$


That is, agents accept national identity if their beliefs about future benefits from sharing national identity is high, i.e., $\bar{\theta}_{i}$ is above some threshold $\kappa^{*}$. There is a unique equilibrium cutoff $\kappa$ for citizens defined by the expectation of future benefits from the nation-state that makes an individual indifferent to choice of accepting national or tribal identity.

The equilibrium participation threshold $\kappa$ is the solution to the equilibrium condition:

$$
\kappa^{N I}=-\frac{\tau}{2}
$$

As Morris and Shin $(1998,2004)$ showed, the equilibrium is unique if regularity conditions hold.

\section{A.3 Condition for uniqueness of equilibrium:}

Let's define $U\left(\kappa^{*}\right)$ as the left-hand side function of the equation (5). A sufficient condition for a uniqueness of the solution is that the left-hand side increases weakly monotonically in $\kappa^{*}$. Here we follow Morris and Shin $(1998,2004)$ proof of uniqueness:

$$
U=\kappa^{*}+\tau\left(\Phi\left(\sqrt{\gamma}\left(p-\kappa^{*}\right)\right)\right)
$$

where $\gamma=\frac{\alpha+\beta}{\alpha^{2}}$. We need the derivative of $U\left(\kappa^{*}\right)$ with respect to $\kappa^{*}$ to be non-negative:

$$
\begin{gathered}
\frac{\partial U}{\partial \kappa^{*}}=1-\tau \sqrt{\gamma} \phi\left(\sqrt{\gamma}\left(p-\kappa^{*}\right)\right) \geq 0 . \\
1 \geq \tau \sqrt{\gamma} \phi\left(\sqrt{\gamma}\left(p-\kappa^{*}\right)\right), \\
1 \geq \tau \sqrt{\gamma} \cdot \phi\left(\sqrt{\gamma}\left(p-\kappa^{*}\right)\right) \quad \geq \tau \sqrt{\gamma} \frac{1}{\sqrt{2 \pi}} .
\end{gathered}
$$

Here we use the fact that standard normal p.d.f. $(\phi(x))$ maximum value is equal to $\frac{1}{\sqrt{2 \pi}}$ at $x=0$ and substituting $\phi(\cdot)$ with $\frac{1}{\sqrt{2 \pi}}$ in equation 10. This gives the sufficient condition for a unique equilibrium:

$$
2 \pi \geq \tau^{2} \gamma
$$

\section{A.4 Empirical Implications}

This model produces a specific testable prediction: people's self-identification with the state goes down if the state becomes observably weaker. This effect is the largest where the information about state weakness is the most precise.

After we have found the equilibrium thresholds $\kappa^{*}$, we can derive the equilibrium participation, $A$ : 


$$
A=\Phi\left(\frac{\frac{\tau}{2}+\theta}{\sqrt{\beta}}\right)
$$

It is continuous and strictly increasing in $\theta$. Thus if the state is weak and the signal is negative $\theta<0$, the share of citizens that chooses national identity decreases.

Proposition: The probability of an agent accepting a national identity and the share of people who accept national identity is increasing (decreasing) in signal about the strength (weakness) of the state $\left(\frac{\partial\left[\operatorname{Prob}\left(a_{i}\left(\bar{\theta}_{i}\right)=1\right)\right]}{\partial \bar{\theta}_{i}}>0\right.$, and $\left.\frac{\partial A}{\partial \bar{\theta}_{i}}>0\right)$.

Proof:

$$
\begin{gathered}
\frac{\partial A}{\partial \bar{\theta}_{i}}=\frac{1}{\beta} \phi\left(\frac{\frac{\tau}{2}+\bar{\theta}_{i}}{\sqrt{\beta}}\right)>0 . \\
\frac{\partial\left[\operatorname{Prob}\left(a_{i}\left(\bar{\theta}_{i}\right)=1\right)\right]}{\partial \bar{\theta}_{i}}=\frac{\alpha}{\sqrt{\beta+\alpha}} \phi\left(\frac{\beta}{\sqrt{\beta+\alpha}} \cdot x_{i}+\frac{\alpha}{\sqrt{\beta+\alpha}} \cdot p-\sqrt{\beta+\alpha} \cdot \bar{\theta}_{i}\right)>0 .
\end{gathered}
$$

Proposition: The share of people who accept national identity is increasing (decreasing) in precision of personal $(\beta)$ signal about the strength (weakness) of the state $\left(\frac{\partial A}{\partial \beta}>0\right)$.

Proof:

$$
\frac{\partial A}{\partial \beta}=-\frac{\tau / 2+\bar{\theta}_{i}}{2 \beta^{3 / 2}} \cdot \phi\left(\frac{\frac{\tau}{2}+\theta}{\sqrt{\beta}}\right)<0 .
$$

Our model predicts two aspects of observed state weakness on national identity. First, as the state becomes weaker, national identity should also become weaker. Second, within a country, the regions most affected by state weakness must see a larger decline in national identity. In this paper, we test those predictions using survey data from the Republic of Mali, a predominantly Muslim West African nation that has recently experienced a surge in political instability. 


\section{B Data Appendix}

\section{B.1 Variable Construction}

All variables used in this paper are taken from the 1-5 waves of Afrobarometer survey for the Republic of Mali.

As national identity can be nonbinary and people can embrace several identities at the same time, for completeness, we also use less strict identification of national identity where a respondent answered that they consider only "national identity" their primary identity, or considered himself or herself more Malian than his/her ethnic group.

The answers on national identity question are slightly different in the second Afrobarometer's wave: (i) I feel Malian; (ii) I feel (R's identity group); (iii) Not applicable; (iv) I don't know. When a respondent said that they consider themselves "Malian," we assign the value of 1 to the $N I_{i t}$ and 0 otherwise. Thus, we could not use this wave to construct the alternative measure of national identity.

We use the following variables throughout the paper as explanatory or dependent variables:

- Urban — indicator variable equal to 1 if respondent lives in urban area, and 0 otherwise.

- Female - indicator variable equal to 1 if respondent is a female, and 0 otherwise.

- Age - age in years.

- Christian - indicator variable equal to 1 if respondent's religion is Christianity or any of its denominations (Catholic, Orthodox, Anglican, Baptist, or Evangelical), and 0 otherwise.

- Muslim - indicator variable equal to 1 if respondent's religion is Muslim or any of its denominations (Sunni, Shia, Mouridiya, Tijaniya, or Qadiriya), and 0 otherwise.

- Traditional beliefs - indicator variable equal to 1 if respondent's religion is a traditional/ethnic beliefs, and 0 otherwise.

- Unemployment - indicator variable equal to 1 if respondent's employment status is employed (full-time or part-time), and 0 otherwise.

- Personal living conditions (changes) - indicator variable equal to 1 if respondent answered that her personal condition become "much better," or "better," and 0 otherwise.

- Personal living conditions - indicator variable equal to 1 if respondent answered that her personal condition is "very good," or "fairly good," and 0 otherwise.

- Country's economic conditions - indicator variable equal to 1 if respondent answered that countries economic condition is "very good," or "fairly good," and 0 otherwise.

- News (weekly) - indicator variable equal to 1 if respondent answered that she receives news weekly at least in one of two forms (newspaper and television), and 0 otherwise. ${ }^{23}$

- News (daily) - indicator variable equal to 1 if respondent answered that she receives news daily at least in one of two forms (newspaper and television), and zero otherwise. This variable is nested within the variable "news (weekly)."

\footnotetext{
${ }^{23}$ We don't use radio because almost everyone is listening it weekly and there is almost no variation.
} 
- Wealth index - computed as a first principle component of four dummy variables of possession of certain assets (radio, television, vehicle, water source at home).

- No water - indicator variable equal to 1 if respondent answered that she gone without water "always," "many times," or "several times," and 0 otherwise.

- No medical care - indicator variable equal to 1 if respondent answered that she gone without medical care "always," "many times," or "several times," and 0 otherwise.

- No electricity - indicator variable equal to 1 if respondent answered that government provides reliable electric supply "always," "many times," or "several times," and 0 otherwise.

- Robbery - indicator variable equal to 0 if respondent answered that nothing was ever stolen from her home ("never"), and assigned 1 otherwise.

- Fear crime - indicator variable equal to 0 if respondent answered that she "never" feared a crime at home, and assigned 1 otherwise.

- The following ethnic groups are defined as "ethnic majority": Malinke/Bambara (41\%), Peulh/Fulfulde (15\%), and Soninke/Sarakoll (10\%).

- The following ethnic groups are defined as "ethnic majority in Azawad" (excluding Tuaregs): Sonrhai (72\%) and Arabs (17\%).

\section{B.2 Aggregation}

For the aggregate panel specification in Table 14, following Ananyev and Guriev (2018), we aggregate the data on the regional and rural/urban levels to increase the number of observations. Afrobarometer surveys are representative cross-sections of all citizens of voting age in a given country. Thus we impose additional assumptions to be able to aggregate the data on the regional and rural/urban level. In particular, we ensure that there are enough observations in each regionrural/urban bin. The average number of respondents in each bin is equal to 100, and the median is 105. The maximum number of observations is 208 and the minimum is 15. All results hold if we drop six observation that have below 30 observations. We use weights provided by Afrobarometer when aggregating the data. 


\section{Additional Robustness and Sensitivity Checks}

\section{C.1 Difference-in-Differences Estimation with Arbitrary Treatment (Mopti)}

Here we provide alternative difference-in-differences specification with arbitrary treatment. We assign Mopti, located within 250 kilometers from the conflict zone's border, to the hypothetical "treatment group" and other regions to the hypothetical "control group." This estimation allows us to rule out the existence of an unobserved constant region-specific factors that could bias our estimates. We add region fixed effects to control for those factors that are additively-linear and constant in time. To control for a time-varying factor, we add both a year fixed effect and an interaction of the fixed effect of Mopti and the year fixed effect. This interaction term now becomes our main coefficient of interest.

The specification is as follows:

$$
N I_{i r t}=\alpha+\beta P O S T_{t}+\delta\left(P_{P S T} \times \text { Exposed }_{r}\right)+X_{i t}^{\prime} \Gamma+\mu_{r}+\varepsilon_{i r t},
$$

where as a dependent variable we use a dummy $N I_{i r t}=0$ if respondent $i$ in region $r$ has identified herself with her ethnic group at time $t \in\{2010,2012\}$ and equal to unity if she identifies herself with the nation. Variable $P O S T_{t}$ is a dummy equal to unity if $t=2012$; Exposed $_{r}$ is a dummy, if the region $r$ is an exposure region (Mopti) for state weakness; $X_{i t}$ is the matrix of individual controls such as age, education, dummy for rural area, household wealth index, religion and ethnicity; and $\mu_{r}$ is a region fixed effect. The coefficient of interest is $\delta$, and we expect it to be negative. As the treatment is on the regional level, we cluster errors on the regional level as well. As there are few clusters, we also report the confidence intervals from the wild bootstrapping (Cameron, Gelbach and Miller (2008)).

We choose Mopti as our main "treated" region, because, as we hypothesize that our treatment effect comes from informational exposure to conflict, Mopti was the only non-rebellious region which shared a common border with the rebellious Azawad region.

We are interested in $\widehat{\delta}$ which is the effect of insurgency when the civil conflict happened. Thus, we use two types of variation: geographical (whether the respondent is within a region [Mopti] located closely to insurgency) and temporal (whether the particular wave of the survey happened after the increase in violence).

As Tuaregs may be more likely to live in Mopti and choose ethnic identity over national identity because of the Tuareg-led rebellion we could overestimate the effect of insurgency. Thus we drop all individuals whose ethnic group is Tuareg; these constitute 2.8 percent of the observations.

Figure 3 visualizes our empirical results. The blue line represents the treatment group, and the red line represents the control group. We see that before the insurgency (round four of the survey), the average levels of national identity have been increasing in all regions, but right after the start of the insurgencies, we see important changes. The level of national identity in the control group continue to increase, but in the treatment group it goes down rapidly. The trends in the dependent variable before the treatment within the treatment group and within the control group are parallel, and the changes in trends coincide with the time of the treatment: both regions experienced almost identical trends between the 3rd and the 4th waves and similar trends between the 2nd and the 3rd Afrobarometer waves. In the next section we directly test for the absence of pre-trends. However, Figure 3 also indicates possible mean-reversal in national identity, and we control for it in all specifications.

We test for balancing properties in Table 16. As evident, the region of Mopti is very different from other non-Azawad Malian regions. It is less urban, poorer, and has fewer college-educated 
respondents. It has higher unemployment, and people there consider the country's economic situation worse while considering their economic situation to be better than those in other regions. Thus, in the next section, we employ an array of control variables to address the pre-insurgency differences in demographic and socioeconomic characteristics of the regions.

\section{C.2 Results}

Results of the OLS estimations are presented in Table 11. In Column I, we present results of the specification with time and regional fixed effects without any individual controls. The coefficient of interest is negative and highly significant: exposure to insurgency in Mopti decreases residents' national identification by 57.8 percentage-points. In Column II, we control for possible meanreversal in the dependent variable by adding lagged region-level national identity. The resulting coefficient remains significant but substantially decreases in magnitude: exposure to insurgency in Mopti decreases residents' national identification by 24.3 percentage-points.

In Columns III-IV, to discern whether urban populations or those with Muslim/Christian affiliation have different reactions to insurgency, we add an indicator variable for urban respondents, and dummies for religions. We also control for age, gender, personal living conditions, education, unemployment, access to news, and the first principal component of household assets, ethnicity fixed effects. Results hold if, as in Column V, we add observations from the other three ethnic Tuareg regions constituting Azawad.

Table 11: Civil conflict and national identity: Individual-level data

\begin{tabular}{|c|c|c|c|c|c|c|c|}
\hline & $\mathrm{I}$ & II & III & IV & $\mathrm{V}$ & $\mathrm{VI}$ & VII \\
\hline & \multicolumn{7}{|c|}{ Dependent variable: } \\
\hline & \multicolumn{5}{|c|}{ National identity } & \multicolumn{2}{|c|}{ Ethnic identity } \\
\hline After civil war (2012) & $\begin{array}{c}0.052 \\
(0.613)\end{array}$ & $\begin{array}{c}0.369^{* * *} \\
(0.008)\end{array}$ & $\begin{array}{c}0.360 * * \\
(0.015)\end{array}$ & $\begin{array}{c}0.361 * * \\
(0.017)\end{array}$ & $\begin{array}{c}0.359 * * * \\
(0.008)\end{array}$ & $\begin{array}{l}-0.051 \\
(0.254)\end{array}$ & $\begin{array}{l}-0.054 \\
(0.193)\end{array}$ \\
\hline Exposed x 2012 & $\begin{array}{c}-0.578 * * * \\
(0.002) \\
{[-0.73 ;-0.43]}\end{array}$ & $\begin{array}{c}-0.243 * * \\
(0.042) \\
{[-0.38 ;-0.11]}\end{array}$ & $\begin{array}{c}-0.247 * * \\
(0.041) \\
{[-0.40 ;-0.10]}\end{array}$ & $\begin{array}{c}-0.269^{* *} \\
(0.029) \\
{[-0.40 ;-0.12]}\end{array}$ & $\begin{array}{c}-0.267 * * \\
(0.017) \\
{[-0.42 ;-0.12]}\end{array}$ & $\begin{array}{c}0.187 * * * \\
(0.005) \\
{[0.13 ; 0.24]}\end{array}$ & $\begin{array}{c}0.168 * * * \\
(0.003) \\
{[0.12 ; 0.22]}\end{array}$ \\
\hline Lagged mean Y & & $\mathrm{X}$ & $\mathrm{X}$ & $\mathrm{X}$ & $\mathrm{X}$ & & $\mathrm{X}$ \\
\hline Controls & & & $\mathrm{X}$ & $\mathrm{X}$ & $\mathrm{X}$ & & $\mathrm{X}$ \\
\hline Ethnicity FE & & & & $\mathrm{X}$ & $\mathrm{X}$ & & $\mathrm{X}$ \\
\hline with Azawad & & & & & X & & \\
\hline R-squared & 0.066 & 0.087 & 0.097 & 0.109 & 0.106 & 0.038 & 0.071 \\
\hline Observations & 2,290 & 2,290 & 2,290 & 2,290 & 2,376 & 2,290 & 2,290 \\
\hline
\end{tabular}

Notes: All columns include constant and regional fixed effects. The following variables are included as controls: urban dummy, religion dummies (Christian, Muslim, and traditional beliefs), age, age squared, gender dummy, dummy for positive change in living conditions, dummy for unemployment, dummies for secondary and tertiary education, dummy for daily access to news, and wealth index. P-values from robust clustered-by-region standard errors are in parentheses. There are 6 clusters in Columns I--III, and VII-VIII. 9 clusters in Columns IV-VI. Wild-bootstrapped 95\% confidence intervals (Cameron, Gelbach and Miller (2008)) are in brackets. ${ }^{* * *}$ $\mathrm{p}<0.01,{ }^{* *} \mathrm{p}<0.05,{ }^{*} \mathrm{p}<0.1$

Our results are robust to a fully dynamic difference-in-differences specification using the data from the second, third, fourth, and fifth Afrobarometer waves (see Table D12). This specification allows us to control for region-specific trends and helps us better control for the secular trend toward national identification (explaining the rapid upswing between the third and fourth waves). Moreover, it allows us to directly test for the absence of pre-trends: joint F-test for $\delta_{2002}=\delta_{2008}=0$ is not rejected for all specifications. 
Table 12: Civil conflict and national identity:Direct test for pre-trends

\begin{tabular}{|c|c|c|c|c|}
\hline & $\mathrm{I}$ & II & III & IV \\
\hline & \multicolumn{4}{|c|}{ Dependent variable: } \\
\hline & \multicolumn{2}{|c|}{ National identity (baseline) } & \multicolumn{2}{|c|}{$\begin{array}{c}\text { National identity } \\
\text { (alternative) }\end{array}$} \\
\hline \multirow[t]{2}{*}{ After civil war (2012) } & $0.446^{* *}$ & $0.313^{*}$ & -0.025 & -0.066 \\
\hline & $(0.012)$ & $(0.070)$ & $(0.409)$ & $(0.467)$ \\
\hline \multirow[t]{2}{*}{ Exposed x 2012} & $-0.582 *$ & $-0.569^{*}$ & $-1.138 * * *$ & $-1.045^{* * *}$ \\
\hline & $(0.082)$ & $(0.069)$ & $(0.000)$ & $(0.000)$ \\
\hline \multirow[t]{2}{*}{ Exposed x 2008} & -0.003 & 0.022 & -0.117 & -0.070 \\
\hline & $(0.993)$ & $(0.938)$ & $(0.265)$ & $(0.438)$ \\
\hline \multirow[t]{2}{*}{ Exposed x 2002} & -0.162 & -0.130 & & \\
\hline & $(0.207)$ & $(0.261)$ & & \\
\hline \multirow[t]{2}{*}{ Before civil war (2008) } & $0.344 * *$ & 0.259 & 0.035 & 0.014 \\
\hline & $(0.021)$ & $(0.104)$ & $(0.730)$ & $(0.917)$ \\
\hline \multirow[t]{2}{*}{ Before civil war (2002) } & $0.268 * * *$ & $0.333 * * *$ & & \\
\hline & $(0.005)$ & $(0.001)$ & & \\
\hline Controls & & $\mathrm{X}$ & & $\mathrm{X}$ \\
\hline Ethnicity FE & & $\mathrm{X}$ & & $X$ \\
\hline Region-specific trends & $\mathrm{X}$ & $\mathrm{X}$ & $\mathrm{X}$ & $\mathrm{X}$ \\
\hline R-squared & 0.127 & 0.142 & 0.121 & 0.142 \\
\hline Observations & 4,877 & 4,877 & 3,594 & 3,594 \\
\hline
\end{tabular}

Notes: Due to the changes in questionnaire we cannot construct dependent variable for the second Afrobarometer wave for Columns III and IV. All columns include constant, wave fixed effects, regional fixed effects, and region-specific linear trends. The following variables are included as controls: urban dummy, religion dummies (Christian, Muslim, and traditional believes), age, age squared, gender dummy, dummy for positive change in living conditions, dummy for unemployment, dummies for secondary and tertiary education, dummy for daily access to news, and wealth index. For all Columns, a joint F-tests that interaction coefficients for years before insurgency being equal to zero $\left(\delta_{2002}=\delta_{2008}=0\right)$ are not rejected. In Column II, a joint F-test that interaction coefficients for years before insurgency being equal to zero is rejected $(\mathrm{p}$-value $=0.004)$. P-values from robust clustered-by-region standard errors are in round parentheses. 9 clusters. ${ }^{* * *} \mathrm{p}<0.01,{ }^{* *} \mathrm{p}<0.05,{ }^{*} \mathrm{p}<0.1$

To check that the results hold with a measure that includes whether the person considers themselves part of the national identity we also report results for the similar specifications but for an alternative, less strict, measure of national identity: equal to one if respondent not only feels only Malian, but also if he/she feels Malian more than his/her ethnic group. Results are presented in Table 13 and show a similar pattern: respondents in exposed region choose national identity over ethnic identity 13.4 percentage-points less. 
Table 13: Civil conflict and national identity:Alternative measure of national identity

\begin{tabular}{|c|c|c|c|c|}
\hline & $\mathrm{I}$ & II & III & IV \\
\hline & \multicolumn{4}{|c|}{ Dependent variable: National identity (alternative) } \\
\hline & \multicolumn{2}{|c|}{$\begin{array}{l}\text { Malian more than her } \\
\text { ethnic group }\end{array}$} & \multicolumn{2}{|c|}{$\begin{array}{l}\text { Malian at least as her ethnic } \\
\text { group }\end{array}$} \\
\hline \multirow[t]{2}{*}{ After civil war (2012) } & 0.066 & $0.410 * * *$ & 0.093 & $0.167 * *$ \\
\hline & $(0.535)$ & $(0.004)$ & $(0.122)$ & $(0.022)$ \\
\hline \multirow[t]{3}{*}{ Exposed x 2012} & $-0.483^{* * *}$ & $-0.137^{*}$ & $-0.233 * * *$ & $-0.211 * * *$ \\
\hline & $(0.005)$ & $(0.099)$ & $(0.006)$ & $(0.007)$ \\
\hline & {$[-0.64 ;-0.32]$} & {$[-0.24 ;-0.01]$} & {$[-0.32 ;-0.15]$} & {$[-.028 ;-0.14]$} \\
\hline Controls & & $\mathrm{X}$ & & $\mathrm{X}$ \\
\hline R-squared & 0.061 & 0.105 & 0.050 & 0.084 \\
\hline Observations & 2,290 & 2,290 & 2,290 & 2,290 \\
\hline
\end{tabular}

Notes: All columns include constant and regional fixed effects. The following variables are included as controls: urban dummy, religion dummies (Christian, Muslim, and traditional believes), age, age squared, gender dummy, dummy for positive change in living conditions, dummy for unemployment, dummies for secondary and tertiary education, dummy for daily access to news, and wealth index. P-values from robust clustered-by-region standard errors are in round parentheses. There are 6 clusters in Columns I-IV and VI-VII, and 9 clusters in Column V. ${ }^{* *} \mathrm{p}<0.01,{ }^{* *} \mathrm{p}<0.05,{ }^{*} \mathrm{p}<0.1$

Inference using standard approaches may lead to underestimated confidence intervals in this setting because of the small number of clusters (nine) in the data. To address this concern, in addition to wild-bootstrapping, we aggregate the data by region-urban level and report results with two small-sample corrections. ${ }^{24}$ We show results for aggregated specification without any controls in Column I of Table 14. As all the variation in treatment comes from the regional level, the coefficients in Table 14 are quite close to corresponding specifications in Table 1. We add urban and rural Azawad observations in Column II. The results remain virtually unchanged. We add the full set of controls in Column III; our results still hold. Finally, in Column IV, we directly control for pretrend in the dependent variable by adding lagged changes in the national identity to the right-hand side of the equation. In Figure 4, we report the residual plot of the national identity and treatment status interacted with a time dummy for the specification in Column IV: our results are not driven by outliers in the data. We report robust standard errors in parentheses. We can tell from these standard errors that the coefficients are statistically significant under standard inference procedures based on asymptotic results.

\footnotetext{
${ }^{24}$ Our small-sample-correction exercises follow Bloom et al. (2013) and Hanlon (2015). Aggregation also shows that our results are not driven by sampling of the Afrobarometer surveys.
} 
Table 14: Civil conflict and national identity: Aggregated data

\begin{tabular}{|c|c|c|c|c|}
\hline & I & II & III & IV \\
\hline & \multicolumn{4}{|c|}{ Dependent variable: National identity } \\
\hline \multirow[t]{2}{*}{ After civil war (2012) } & 0.353 & 0.363 & 0.353 & 0.446 \\
\hline & $(0.012)$ & $(0.010)$ & $(0.013)$ & $(0.003)$ \\
\hline \multirow[t]{2}{*}{ Exposed x 2012} & $-0.293 *$ & $-0.285^{*}$ & $-0.281 *$ & $-0.479 * * *$ \\
\hline & $(0.061)$ & $(0.072)$ & $(0.074)$ & $(0.009)$ \\
\hline Imbens \& Kolesar p-value & {$[0.056]$} & {$[0.070]$} & {$[0.082]$} & [0.007] \\
\hline Permutation-approach p-value & {$[[0.018]]$} & {$[[0.001]]$} & {$[[0.001]]$} & {$[[0.001]]$} \\
\hline \multirow[t]{2}{*}{$\Delta$ National identity (2008-2005) } & & & & -0.974 \\
\hline & & & & $(0.008)$ \\
\hline with Azawad & & $\mathrm{X}$ & $\mathrm{X}$ & $\mathrm{X}$ \\
\hline Controls & & & $X$ & \\
\hline R-squared & 0.787 & 0.786 & 0.813 & 0.839 \\
\hline Observations & 22 & 24 & 24 & 24 \\
\hline
\end{tabular}

Notes: All columns include constant, region, and urban fixed effects. Data is aggregated on the regional and urban level. The median number of respondents per aggregation is 120 , minimum is 52 . The following variables are included as controls in Column III: age, shares of women, unemployment, Muslims, Christians, people with traditional beliefs, people with secondary and tertiary education, personal living conditions, daily access to news, and wealth index. P-values from robust standard errors are in parentheses. Single brackets contain p-values from a test based on $\mathrm{HC} 2$ standard errors tested against a t-distribution with degrees of freedom determined using Welch's (1947) formula. E.g., for the specification in Column IV, Welch's approach gives a degree of freedom of 9. Double brackets contain p-values from a permutation-based approach in which we select every permutation of two regions (Mopti-urban and Mopti-rural) out of the 11 regions (11 choose $2=78$ ) in Column I and select every permutation of four regions (Mopti and Azawad, and rural and urban) out of the 13 regions $(13$ choose $4=715)$ in Columns II--IV and estimate the impact on treated regions after the Tuareg rebellion. We then use the distribution of these "placebo" coefficients to construct the p-value of the treatment coefficient. ${ }^{* * *}$ $\mathrm{p}<0.01,{ }^{* *} \mathrm{p}<0.05,{ }^{*} \mathrm{p}<0.1$

In the single brackets, we follow Imbens and Kolesar (2016) by calculating heteroskedasticityrobust HC2 standard errors (MacKinnon and White (1985)) and then conduct inference using a t-distribution with data-determined degrees of freedom based on the formula from Welch (1947). In double brackets, we present p-values from a permutation-based approach to compute standard errors. In Column I, we permutate two (Mopti-urban and Mopti-rural) of the 11 groups in the analysis, and treat them as if they were the treated by the insurgency. We use four of the 13 treated groups in Columns II-IV (we add Azawad-rural and Azawad-urban). This generates $\frac{13 !}{4 !(13-4) !}=715$ coefficient estimates. ${ }^{25}$ Under the null hypothesis of no effect, these coefficients will have the same distribution as the coefficients that we estimate in Table 14; they can be used for inference with exact size. Under both sample-correction approaches, our coefficients of interest remain highly significant, supporting our hypothesis that insurgency decreases national identity. ${ }^{26}$

\footnotetext{
${ }^{25}$ Another reason, why we aggregate on the rural/urban level in addition to the regional level is to have larger number of treated observations and as a result larger number of permutations.

${ }^{26}$ Permutation based approach delivers results which are much stronger than those from the Imbens and Kolesar (2016) approach. The difference comes from conducting inference with a t-distribution with very few degrees of freedom. This is a very conservative distribution and the p-values in single brackets should be viewed as very conservative.
} 
Figure 4: Residual plot: National identity and the interaction term (aggregated)

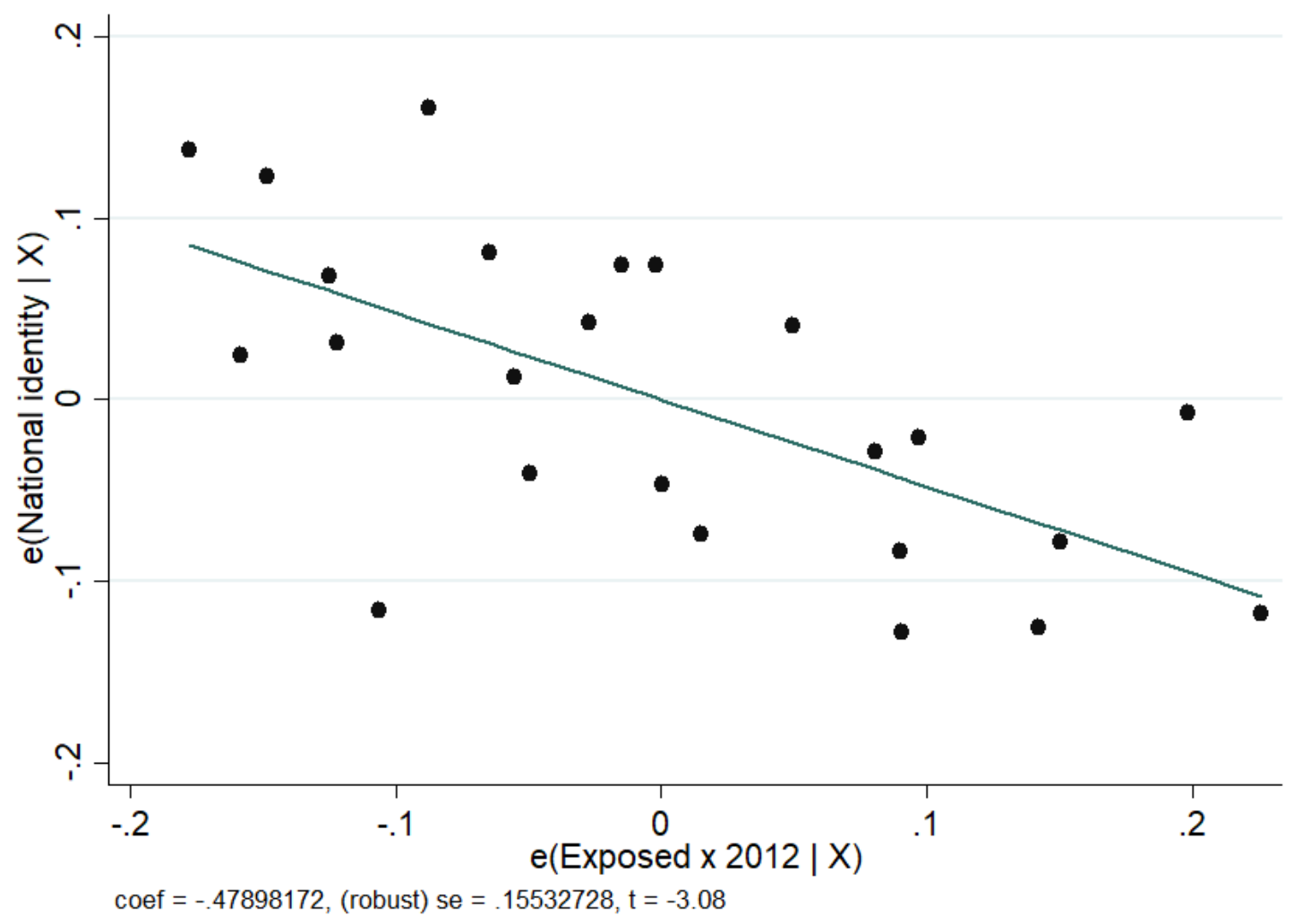

Notes: Added-variable plot computed using the specification from Column IV of Table 14.

One of the explanations behind the relative decrease in national self-identification of Malians in the exposed region could be through the substitution of national identity with ethnic identity as their primary identity. Using our baseline specification in Columns VII of Table 11, we estimate that respondents in exposed regions are 16.8 percentage points more likely to identify themselves with their ethnic group. These results suggest that national identity is being substituted with ethnic identity as a result of civil insurgency (63\% of the fall in national identity is substituted with the rise in ethnic identity).

\section{C.3 Matching}

As Mopti is different from other regions by demographics and ethnic composition, and as Afrobarometer's survey might not be representative at a regional level, we attempt to address this concern in this section by employing exact matching. We choose the following variables for the matching: urban/rural, schooled/not schooled, female/male, and young/senior indicators for all ethnic groups. Matching by these parameters results in 36 matched cells and 989 observations. We present coefficient plots of our results in Panel A of Figure 5. The resulting coefficients do not differ from the baseline results in Table 1 suggesting that our results are meaningful.

As the pool of respondents can change we also perform exact matching across time periods in Panel B of Figure 5. The number of matched observations falls to 452; however, our results hold.

We also report results for other types of matching estimators to show that they are robust to the way in which we execute matching. Columns I-IV of Table 15 contain results of matching across 
groups, while Columns V-VIII contain results of matching across groups and periods. Using the pscore command in Stata (Becker and Ichino (2002)) we estimate nearest neighbor, radius, kernel, and stratification matching estimators. Resulting coefficients are very stable and do not depend on the type of matching, supporting our main finding. 


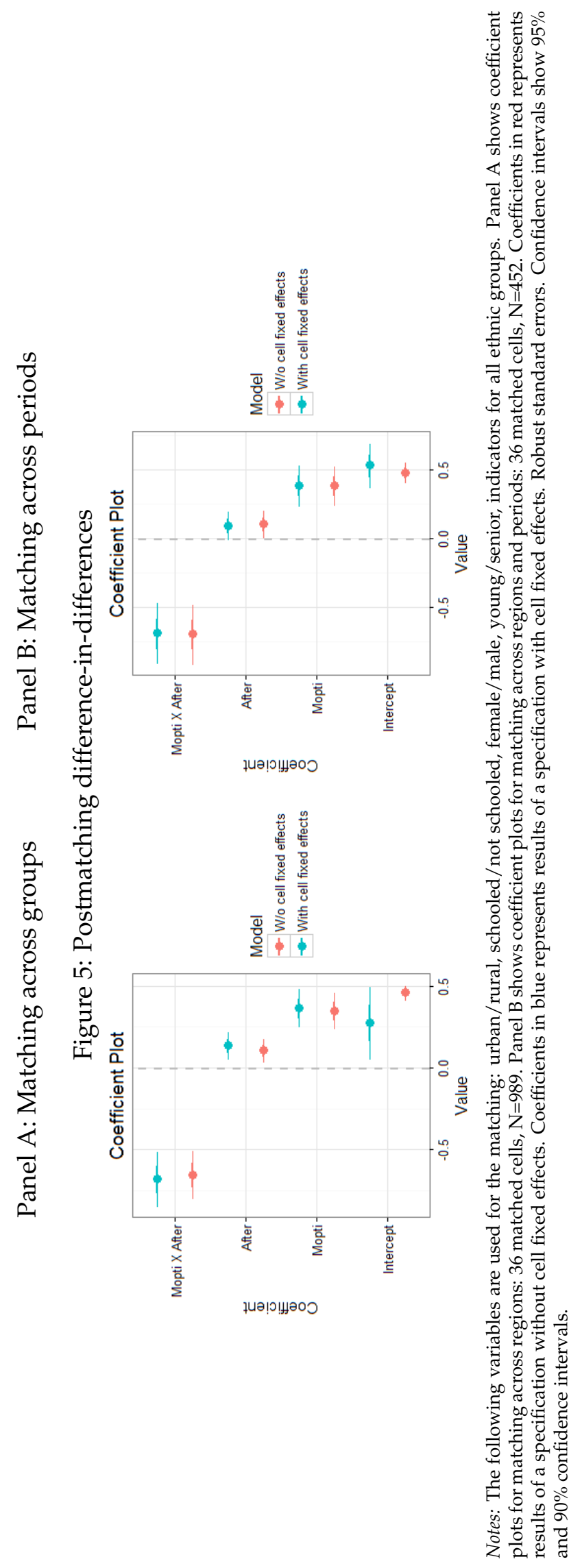




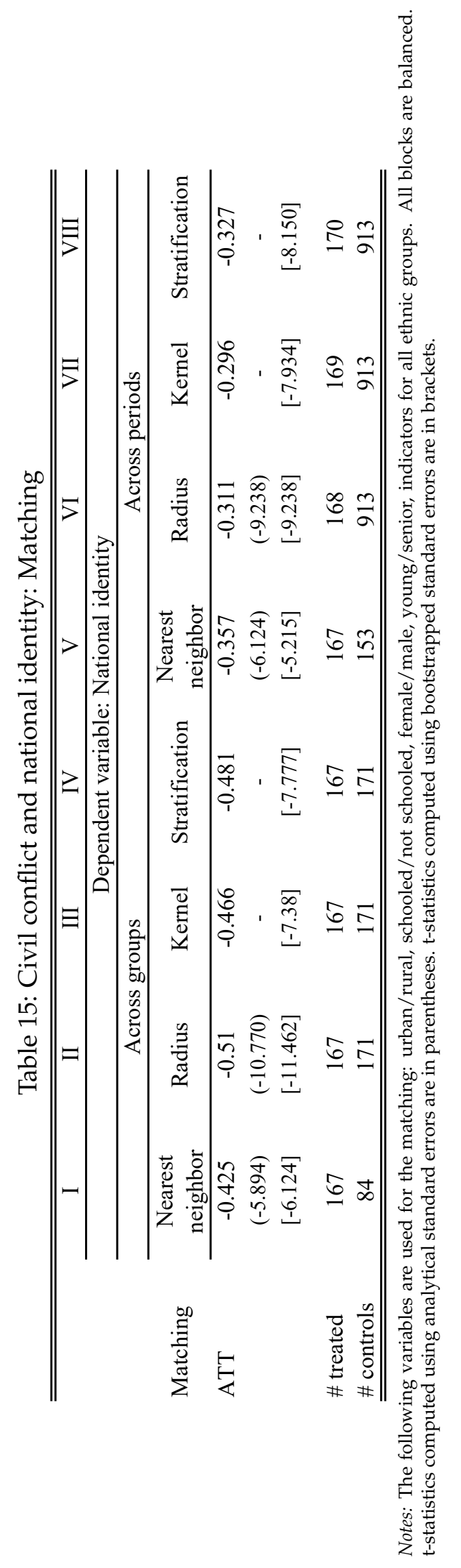




\section{Additional Tables and Figures}

Table 16: Summary statistics (4th and 5th Afrobarometer's waves)

\begin{tabular}{|c|c|c|c|}
\hline Name & Control & Treatment & t-stat for difference \\
\hline \hline Age & 39.7 & 40.4 & 1.08 \\
\hline Urban & 0.32 & 0.19 & -7.08 \\
\hline Female & 0.50 & 0.48 & -1.09 \\
\hline Christian & 0.68 & 0.68 & 0.88 \\
\hline Islam & 0.28 & 0.30 & 1.2 \\
\hline Unemployed & 0.15 & 0.12 & 2.6 \\
\hline Secondary education & 0.05 & 0.05 & 0.05 \\
\hline Tertiary education & 0.035 & 0.007 & -2.7 \\
\hline Living conditions & 0.25 & 0.25 & -0.41 \\
\hline Econ. perceptions & 0.14 & 0.31 & 6.5 \\
\hline Asset wealth index & 0.75 & 0.59 & -6.1 \\
\hline Number of observations & 1,944 & 488 & \\
\hline
\end{tabular}

Notes: Treatment regions: Mopti. Control regions: Bamako, Kayes, Koulikoro, Ségou, and Sikasso. 


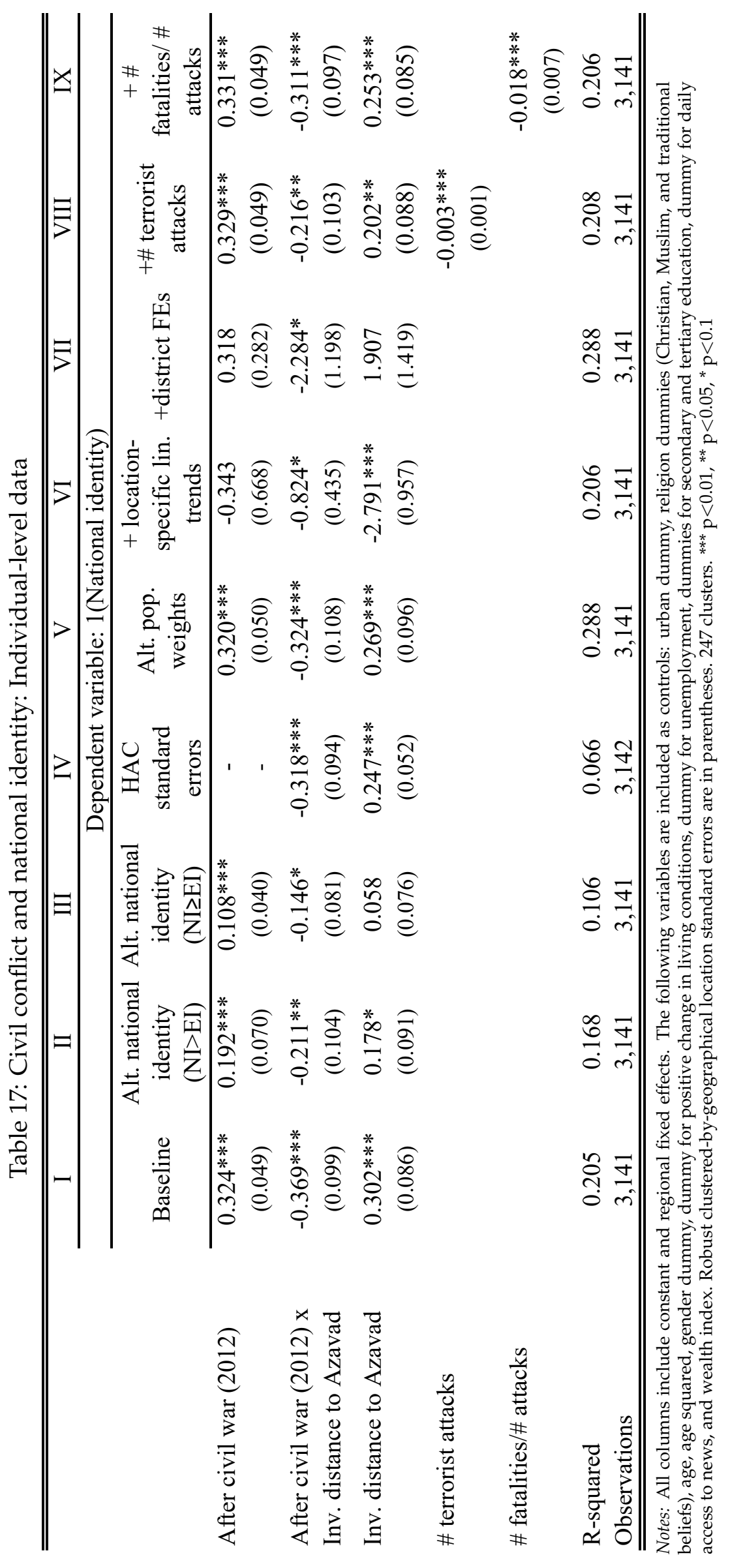




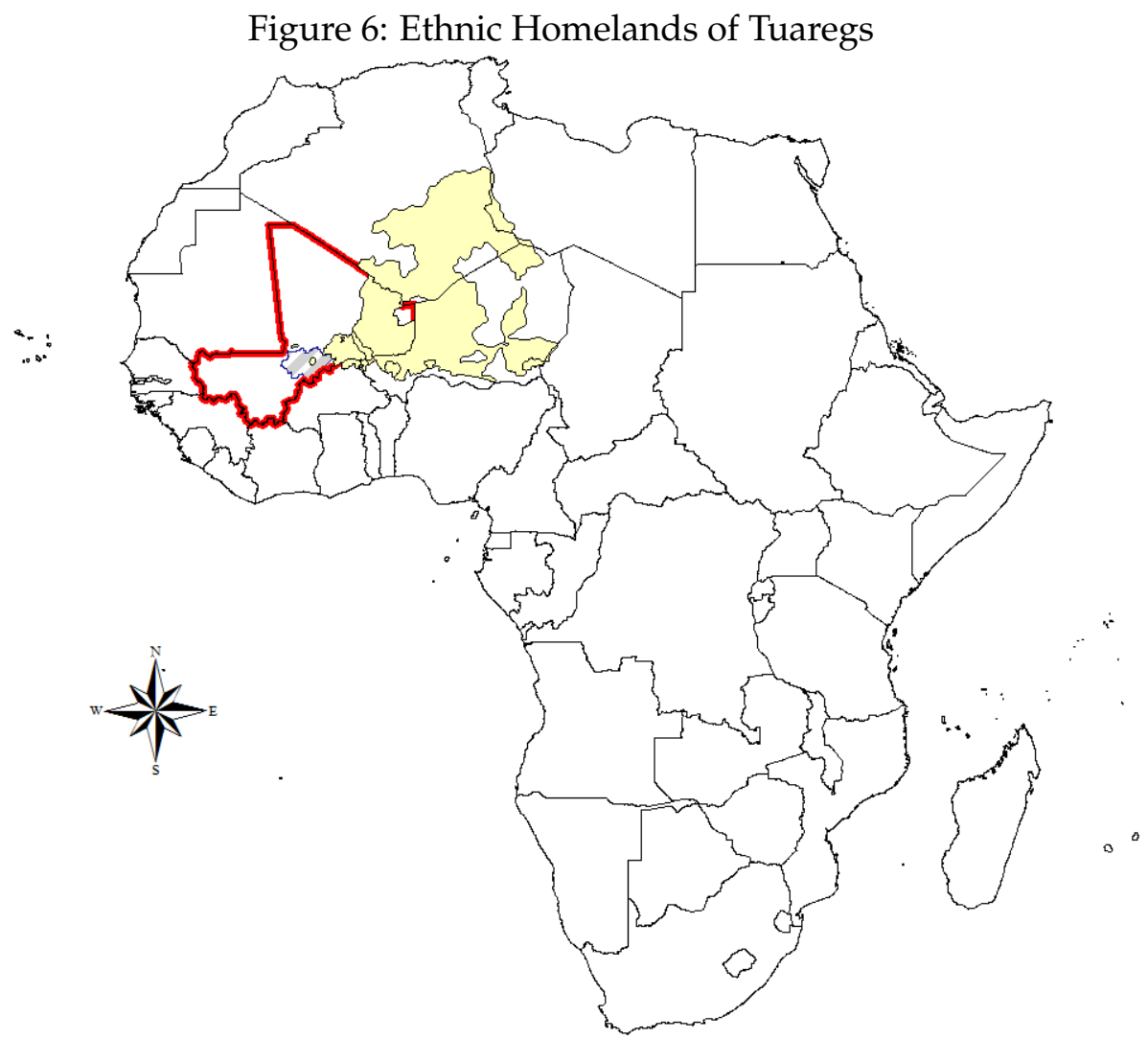

Notes: The red line indicates Malian border. Tuareg homelands are depicted in yellow color. Shaded area indicates Mopti. Source: The historical data on the Tuareg homelands are taken from the georeferencing of ethnic groups (GREG), that is a digitalized map of the Soviet Ethnographic Atlas "Atlas Narodov Mira." 